\title{
Primordial Niger Delta, Petroleum Development in Nigeria and the Niger Delta Development Commission Act: A Food For Thought!
}

\author{
Edward T. Bristol-Alagbariya* \\ Associate Dean \& Senior Multidisciplinary Lecturer, Faculty of Law, University of Port Harcourt, \\ NIGERIA; Affiliate Visiting Fellow, University of Aberdeen, UNITED KINGDOM; and Visiting \\ Research Fellow, Centre for Energy, Petroleum \& Mineral Law and Policy (CEPMLP), Graduate \\ School of Natural Resources Law, Policy \& Management, University of Dundee, Scotland, UNITED \\ KINGDOM \\ * E-mail of the corresponding author: ebristolalagbariya@gmail.com
}

\begin{abstract}
The historic and geographic ethnic minority Delta region of Nigeria, which may be called the Nigerian Delta region or the Niger Delta region, has been in existence from time immemorial, as other primordial ethnic nationality areas and regions, which were in existence centuries before the birth of modern Nigeria. In the early times, the people of the Niger Delta region established foreign relations between and among themselves, as people of immediate neigbouring primordial areas or tribes. They also established long-distance foreign relations with distant tribes that became parts and parcels of modern Nigeria. The Niger Delta region, known as the Southern Minorities area of Nigeria as well as the South-South geo-political zone of Nigeria, is the primordial and true Delta region of Nigeria. The region occupies a very strategic geographic location between Nigeria and the rest of the world. For example, with regard to trade, politics and foreign relations, the Nigerian Delta region has been strategic throughout history, ranging, for instance, from the era of the Atlantic trade to the ongoing era of petroleum resources development in Nigeria. Ancient Niger Delta represents a distinct area of primordial African civilisation. So, the existence of the oil-rich ethnic minority Delta region predates petroleum resources development operations in Nigeria, which operations commenced with the discovery of commercial quantities of crude oil in the oil producing communities of the region in the late 1950s. Thereafter, when petroleum resources were discovered in the communities of neighbouring States of the true Niger Delta region, namely Abia and Imo States of the Igbo major ethnic group, and Ondo State of the Yoruba major tribe, these three oil producing States became integrated into the framework of the true Delta region, by virtue of the Niger-Delta Development Commission (Establishment, Etc.) (NDDC) Act, 2000 (as NDDC States). This Act made the Niger Delta region to be synonymous with petroleum resources development. It is significant to highlight that ceaseless agitation of citizens and citizen-groups of the oil-rich ethnic minority Delta region helped to persuade the Federal Government (FG) to take appropriate steps to address the age-long problems of neglect, marginalisation and deprivation of the region. The agitation of interest groups of the Niger Delta region stems from the fact that whereas the region has been the goldmine of Nigeria, it is experiencing paradoxes associated with unsustainable petroleum resources development operations. These paradoxes made the Delta region to become endangered and crises-ridden as well as generated the region's historic 'resource control' movement, which advocates that the region deserve to have maximum benefits from petroleum development operations in its oil-rich communities. Consequently, through the National Assembly, the FG led by President Olusegun Obasanjo had to take key steps, one of which was the enactment of the NDDC Act that formally repealed the Oil Mineral Producing Areas Development Commission Decree (OMPADEC) Decree, No. 23 of 1992, and dissolved the Commission established thereby. Therefore, the aim of this study is to demonstrate that the true Niger Delta region is distinct and thus improperly categorised with other oil producing States and areas in the context and framework of the NDDC Act. This is a food for thought that warrants serious consideration, analysis and evaluation. Consequently, the study recommends that there is a need for the FG, through the National Assembly, to further amend the NDDC Act, to make its provisions align more with petroleum resources development and that meanwhile the erroneous manner of referring to or considering the Niger Delta region as the 'Nigerian Niger Delta region' or the 'Niger Delta region of Nigeria', should, at least, be corrected in the parlance of the knowledge industry, by stakeholders of the industry, particularly scholars, beginning with Nigerian scholars.
\end{abstract}

Keywords: Ancient; Primordial; Niger Delta; Delta; Petroleum Resources; Petroleum Development; Nigeria; NDDC; Ethnic Minority; Ethnic Minorities; Ethnographic, Historic and Geographic; Ethnic Nationality; Ethnic Nationalities.

DOI: $10.7176 / \mathrm{DCS} / 10-3-10$

Publication date:March $31^{\text {st }} 2020$ 


\section{Introduction}

The historic and geographic ethnic minority Delta region of Nigeria, widely known as the Niger Delta region, has been in existence from time immemorial, ${ }^{1}$ as other primordial ethnic nationality areas and regions, which were in existence centuries before the birth of modern Nigeria. In the early times, the people of the Niger Delta region, also referred to as the Nigerian Delta region, established foreign relations between and among themselves, as people of immediate neigbouring primordial areas. ${ }^{2}$ They also established long-distance foreign relations with distant tribes that became parts and parcels of modern Nigeria. ${ }^{3}$

The Niger Delta region, known as the Southern Minorities area of Nigeria as well as the South-South geo-political zone of the Federal Republic of Nigeria (FRN), is the primordial and true Delta region of Nigeria. ${ }^{4}$ This region occupies a very strategic geographic location between Nigeria and the rest of the world. This situation has been so, throughout history, ${ }^{5}$ ranging, for instance, from the era of the Atlantic trade in slaves and forest products, to the ongoing era of petroleum resources development in Nigeria. ${ }^{6}$ During the Nigerian Civil War (1967 - 1970), the Delta region was the bride of the Federal military and the secessionist (Biafran) military. Hence, the Bight of Bonny played a key strategic role in the Civil War. ${ }^{7}$ Bonny was thus the first place to be liberated in the then Eastern Region by the Federal forces. ${ }^{8}$ It was from Bonny that the new Government of Rivers State (among the first twelve States created by the Federal Military Government (FMG), led by General Gowon, during the Civil War in 1967) ${ }^{9}$ began its administration. Together with Elem Kalabari (Ancient Kalabari [Old Calabar]) Trading State and later on the New Calabar Trading State, as well as Benin Kingdom and the Itsekiri (Warri Trading State),

${ }^{1}$ E. J. Alagoa, A History of the Niger Delta (Onyoma Research Publications 2005); E. J. Alagoa and A. A. Derefaka (eds), The Land and People of Rivers State: Eastern Niger Delta (Onyoma Research Publications 2002); E. J. Alagoa (ed), The Land and People of Bayelsa State: Central Niger Delta (Onyoma Research Publications 1999); E. J. Alagoa et al (eds), The Izon of the Niger Delta (Onyoma Research Publications 2009).

${ }^{2}$ N. Briggs et al (eds), The Economic Development of Rivers State: In Commemoration of Port Harcourt Celebration 2013 (Onyoma Research Publications 2013), 61-66.

${ }^{3}$ Ibid, 67-85.

${ }^{4}$ E. J. Alagoa (2005 [n1]); E. J. Alagoa and A. A. Derefaka (eds) (2002 [n1]); E. J. Alagoa (ed), The Land and People of Bayelsa State: Central Niger Delta (Onyoma Research Publications 1999); E. J. Alagoa et al (eds) (2009 [n1]); Nigerian Guide, 'The Six Geopolitical Zones in Nigeria \& Their States' < https://nigerianguide.com.ng/sixgeopolitical-zones-in-nigeria-their-states/>; A. Yahaya (Nigerianinfopedia), 'List of Six Geopolitical Zones in Nigeria And Their States' <https://nigerianinfopedia.com.ng/six-geopolitical-zones-in-nigeria-and-their-states/> both Accessed 27 March, 2020.

${ }^{5}$ K. O. Dike, Trade and Politics in the Niger Delta 1830-1885: An Introduction to the Economic and Political History of Nigeria (Greenwood Press 1981); G. I. Jones, The Trading States of the Oil Rivers: A Study of Political Development in Eastern Nigeria (Oxford University Press 1963/James Currey Publishers 2000).

${ }^{6}$ I. Onoh, Niger Delta and the Oil and Gas Industry: A Critique of the Impacts and Human Right Implications of the Oil and Gas Industry in the Niger-Delta (LAP LAMBERT Academic Publishing 2011); E. T. BristolAlagbariya, Participation in Petroleum Development: Towards Sustainable Community Development in the Niger Delta (Centre for Energy, Petroleum \& Mineral Law \& Policy [CEPMLP]/Dundee University Press [DUP] 2010); K. S.A. Ebeku, Oil and the Niger Delta People in International Law: Resource Rights, Environmental and Equity Issues (Rüdiger Köppe Verlag Köln 2006); O. Douglas and I. Okonta, Where Vultures Feast: Shell, Human Rights, and Oil in the Niger Delta (Sierra Club 2001); I. Gary and T. L. Karl, Bottom of the Barrel: Africa's Oil Boom and the Poor (Catholic Relief Services 2003); A. A. Ikein, The Impact of Oil on a Developing Country: The Case of Nigeria (Praeger Publishers 1990); B. Manby, The Price of Oil: Corporate Responsibility and Human Rights Violations in Nigeria's Oil Producing Communities (Human Rights Watch 1999); K. Omeje, High Stakes and Stakeholders: Oil Conflict and Security in Nigeria (Routledge 2016); K. Oyende, Oil Pollution Law and Governance in Nigeria (Stirling-Horden Publishers 2017); K. Augustine and C. C. Wigwe, 'The Impact of International Oil and Gas Politics on the Petroleum Industry in Nigeria' [2018] 8 (1) The Journal of Property Law and Contemporary Issues, 142-148; Department of Political Science, Niger Delta University, International Conference on The Nigerian State, Oil Industry and the Niger Delta, Conference Proceedings (Harey Publications Company 2008).

${ }^{7}$ Bight of Bonny Act, No. 4 of 1975, Cap 34 Laws of the Federation of Nigeria (LFN) 1990, Cap B7 LFN 2004; O. Obasanjo, My Command: An Account of the Nigerian Civil War, 1967-1970 (Heinemann 1981); Bight of Bonny during the Eastern Regional era also called Bight of Biafra.

${ }^{8} \mathrm{C} / f$ E. J. Alagoa and A. Fombo (n8), vii-viii.

${ }^{9}$ N. Omoigui, 'Gowon's Speech Creating 12 States: Gowon's broadcast to the Nation - May 27, 1967' $<$ https://www.dawodu.com/gowon.htm> Accessed 27 March, 2020; J. D. Clarke, Yakubu Gowon: Faith in United Nigeria: Faith in a United Nigeria (Frank Cass and Company 1987); C. Achebe, There Was A Country: A Personal History of Biafra (Penguin Group 2012). 
Bonny Kingdom, City and Trading State of the Niger Delta occupied a very strategic position in the history of Ancient Niger Delta region. Bonny remains strategic in modern Nigeria. ${ }^{1}$

The Niger Delta region is often mistakenly referred to as the 'Niger Delta region of Nigeria' and the 'Nigerian Niger Delta region'. ${ }^{2}$ The existence of the oil-rich ethnic minority Delta region predates petroleum resources development operations in Nigeria, which operations commenced with the discovery of commercial quantities of crude oil in the oil producing communities of the region in the late $1950 \mathrm{~s}$. Thereafter, petroleum resources were discovered in the communities of neighbouring States of the true Niger Delta region, namely from Abia and Imo States of the Igbo major ethnic group, as well as Ondo State of the Yoruba major tribe (albeit basically in Ijaw ethnic minority areas of Ondo State). Perhaps, for purposes of administrative convenience, these new oil producing States became integrated into the true Delta region, by virtue of the Niger-Delta Development Commission (Establishment, Etc.) (NDDC) Act, 2000 (as NDDC States). ${ }^{3}$ This Act is designed to address how to sustainably develop the Niger Delta area and to tackle the ecological and generic environmental problems of the area occasioned as a result of decades of petroleum resources development operations in the area. ${ }^{4}$

The NDDC Act categorises the States of the true Niger Delta region and other oil producing States of Nigeria as oil producing States ${ }^{5}$ without considering other distinguishing features of these States, such and the historical background and other peculiarities of their component ethnic nationalities, kingdoms and communities. Thus, whereas it is correct to say that these States are oil producing States, they are nevertheless much more than oil producing States in the context of such realities as ethnography, history and geography. Against this background, some, particularly interest groups of the true Niger Delta, began to describe, regard or refer to the Act's new idea of the Niger Delta as being politically diluted. ${ }^{6}$

Therefore, the aim of this study is to demonstrate that the true Niger Delta region is distinct and thus being improperly categorised with other oil producing States and areas in the context and framework of the NDDC Act. The study considers that such a diluted and misleading idea of the Niger Delta amounts to a food for thought, which warrants serious consideration, especially scholarly analysis and examination. Consequently, it makes a case for further amendment of the NDDC Act, so as to make its provisions to align more with petroleum resources development. It also makes a case for scholars to correct the increasingly prevailing erroneous and misleading reference to or consideration of the Niger Delta region as the 'Nigerian Niger Delta region' or the 'Niger Delta Region of Nigeria', as there is only one Niger Delta or Niger Delta region; that is, the Nigerian Delta region. ${ }^{7}$

2. Primordial Niger Delta: From Earliest Times to the Era of the Willink Commission of Enquiry, 1957 It is pertinent to discuss this sub-heading in two parts: 'The term Delta' and the 'Primordial Niger Delta' area.

\footnotetext{
${ }^{1}$ Alagoa and A. Fombo (n8), vii-viii.

${ }^{2}$ V. Ojakorotu, Oil Exploitation and Conflict in the Niger-Delta Region of Nigeria (APSS Press 2009); V. Ojakorotu (ed), Fresh Dimensions on the Niger Delta Crisis of Nigeria (JAPSS Press 2009); A. C. Uzoma and O. O. Mgbemena, 'Evaluation of Some Oil Companies in the Niger Delta Region of Nigeria: An Environmental Impact Approach' [2015] 3 (2), International Journal of Environment and Pollution Research, 13-31; J. Akpokodje and S. Salau, 'Oil Pollution and Agricultural Productivity in the Niger Delta of Nigeria' [2015] 6 (4) Journal of Environmental Economics, 68-75; N. S. Akpan and E. M. Akpabio, 'Oil and Militancy in Nigeria's Niger Delta: A “Development Catalyst” or "Development in Reverse”?' [2008] 10 (2) South South Journal of Culture and Development, 265-285; S. I. Omofonmwan and L. O. Odia, 'Oil Exploitation and Conflict in the Niger-Delta Region of Nigeria’ [2009] 26 (1) Journal of Human Ecology, 25-30; N. S. Akpan and E. M. Akpabio, 'Oil and Conflicts in the Niger Delta Region, Nigeria: Facing the Facts' [2009] 24 (1) Journal of Social Development in Africa, 9-35; J. S. Omotola, 'From the OMPADEC to the NDDC: An Assessment of State Responses to Environmental Insecurity in the Niger Delta, Nigeria' [2007] Africa Today, 73-89; A. Ogidiolu, 'Effects of Gas Flaring on Soil and Vegetation Characteristics in Oil Producing Region of Niger Delta, Nigeria' [2003] 1 (1), International Journal of Ecology and Environmental Dynamics, 47-53.

${ }^{3}$ Section 1 (2) (b), Niger-Delta Development Commission (Establishment Etc.) (NDDC) Act, No. 6 LFN 2000, Cap N86 LFN 2004; Section 1, NDDC Act is captioned 'Establishment of the Niger-Delta Development Commission'; Section 4 of the Act, entitled 'Rotation of Office of Chairman of the Commission'; Section 30 of the Act, headed 'Interpretation', regarding the interpretation of the meaning of 'member states' and the interpretation of the meaning of 'oil'; Niger Delta Development Commission (Establishment, Etc.) (NDDC) Amendment Act, 2017.

${ }^{4}$ Section 7 (2) (b), Niger-Delta Development Commission (Establishment Etc.) (NDDC) Act, No. 6 LFN 2000, Cap N86 LFN 2004, captioned 'Functions and powers of the Commission'.

${ }^{5}$ E. T. Bristol-Alagbariya (2010 [n6]), 31 and 35-36.

${ }^{6}$ Ibid.

${ }^{7}$ Ibid.
} 


\subsection{Delta}

The word 'delta' could be a Greek alphabet letter (the fourth letter of the Greek alphabet). It could thus be considered as the Greek capital delta or anything triangular, which describes a low-lying triangular plain that is composed of stream-borne sediments deposited by a river at its mouth; that means, where the river divides into several smaller rivers, before flowing into a sea or an ocean. ${ }^{1}$ It is normally a triangular mass of sediment, especially silt and sand, deposited at the mouth of a river, which flows into a body of standing water, such as a sea or lake, and deposits large quantities of sediment. Numerous streams and channels usually cross a delta area, and such an area has exposed as well as submerged components. ${ }^{2}$ So, a delta is formed at the mouth of a river, where the river deposits the sediments carried by it and branches out into distributaries that flow into the sea or lake or another water body. ${ }^{3}$

Deltas are wetlands that form as rivers, which empty their water and sediment into another body of water, such as an ocean, lake or another river. However, exceptional forms of deltas empty their water and sediment into land. ${ }^{4}$

Although most deltas around the globe are triangular in shape, such as the Niger delta, some exceptions exist. ${ }^{5}$ There are therefore many types of deltas. Based on the factors that influenced how delta areas were formed and how they generated their distinct shapes, they may be in any of the following forms: (i) Tide or Wavedominated deltas like the Nile River (Nile delta) along the Mediterranean Sea; (ii) Wave-dominated deltas, such as the Ganges-Brahmaputra delta in India and Bangladesh; (iii) Gilbert deltas, such as Lake Bonneville and the mouths of several creeks that flow into Okanagan Lake in British Columbia to form prominent peninsulas at Naramata, Summerland and Peachland in British Columbia, Canada; and (iv) Estuarine deltas like the Yellow River of China and the estuary of the Tagus River in Portugal, which empties into the Atlantic Ocean near Lisbon. Also, based on their shapes, deltas may be (v) Arcuate (triangular [triangle-shaped], arc-like or fan-shaped) deltas, such as the Niger (Nigerian) delta that empties into the River Niger and the Nile delta in Egypt that empties into the Mediterranean Sea; (vi) Cuspate deltas, such as the mouth of the Tiber River on the Tyrrhenian Sea, near Rome; (vii) Bird-foot deltas like the Mississippi River that drains into the Gulf of Mexico; (viii) Inverted deltas such as the Sacramento-San Joaquin River in northern California, United States of America (USA); (ix) Inland deltas like Okavango delta in Botswana, which spreads its water along a flat plain in the Kalahari Desert; and (x) Abandoned deltas like those of the Mississippi River. ${ }^{6}$ Based on the factors that influenced how they are formed and their peculiar shapes, some types of deltas may fit into more than one type or form of the deltas identified above. For example, considering how it was formed and its distinct shape, the Nile delta (Nile River) in Egypt may be considered as an arcuate delta as well as a wave-dominated delta, due to the wave-breaking feature of its upper and low-lying spheres. ${ }^{7}$

\subsection{Overview of the Beneficial Nature of Delta Areas}

Delta areas around the world are beneficial or useful to humans and society at large. From time immemorial, delta regions have been significant to humans and society at large, as their sands, silts, clays and other sediments and resources are useful to humanity and society at large. Major civilisations flourished in the deltaic plains of the Nile and Tigris-Euphrates rivers. Recently, geologists have discovered much of the world's petroleum in ancient deltaic rocks, ${ }^{8}$ as is the case of the Nigerian Delta area or region. Besides its abundant crude oil resource, the oil-rich Delta region of Nigeria is a source of livelihood in many other respects. As such, the region provides other services associated with its peculiar environment, to its inhabitants. For instance, vast areas of the region serve as fishing grounds and areas for obtaining other forms of water resources for its inhabitants. Areas of the Niger Delta region also serve as farmlands for its inhabitants.

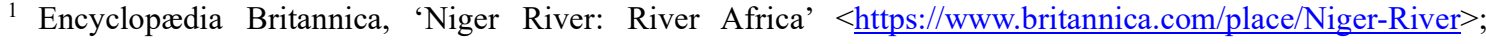
Cambridge Dictionary, 'Delta' $<$ https://dictionary.cambridge.org/dictionary/english/delta $>$; The American Heritage Science Dictionary, 'delta' <https://www.dictionary.com/browse/delta $>$ all Accessed 27 March, 2020.

${ }^{2}$ The American Heritage Science Dictionary (n17).

${ }^{3}$ Worldatlas, 'How Many Types Of Deltas Are There?'<https://www.worldatlas.com/articles/how-many-types-ofdeltas-are-there.html > Accessed 27 March, 2020.

${ }^{4}$ National Geographic Society, 'Delta' < https://www.nationalgeographic.org/encyclopedia/delta/> Accessed 27 March, 2020.

${ }^{5}$ Encyclopaedia Britannica, 'Delta: River System Component' $<\underline{\text { https://www.britannica.com/science/delta-river- }}$ system-component $>$; Worldatlas, 'What Is A River Delta?' < https://www.worldatlas.com/articles/what-is-a-riverdelta.html $>$ both Accessed 27 March, 2020.

${ }^{6}$ Worldatlas (n21); Encyclopædia Britannica (n17).

${ }^{7}$ National Geographic Society (n20).

${ }^{8}$ Encyclopædia Britannica (n17).
} 


\subsection{The Oil-rich Niger Delta Wetland}

The oil-rich Niger Delta region is one of the world's largest wetlands. ${ }^{1}$ It is the largest wetland in Africa and the world's third largest wetland, after the Mississippi River Delta and the Pantanal wetland. ${ }^{2}$

Wetlands occur where water meets land. ${ }^{3}$ This implies that a wetland is a link between land and water. It is a place where land is covered by water, which may either be entire salt-water or fresh-water, or partially salt and fresh water. Examples of wetland areas are edges of lakes or oceans, or even the mouth of rivers, or frequently flooding low-lying areas, rivers, lakes, deltas, mangrove forest areas, peat-lands, marshes, floodplains and flooded forests, rice-fields and coral reefs. ${ }^{4}$ Many wetlands are transitional zones between upland and aquatic ecosystems, although others are scattered across the landscape of upland depressions that collect water or in zones where groundwater comes to the Earth's surface. Wetlands are transitional zones between terrestrial and aquatic systems, where the water table is usually at or near the surface, or the land is covered by shallow water. For instance, wetlands could be transitional zones where the flow of water, the cycling of nutrients and solar energy meet to produce a unique ecosystem characterised by hydrology (water saturation), soils and vegetation; thus making these areas very important features of watershed. Wetlands are areas where water covers the soil, or is present either at or near the surface of the soil all year or for varying periods of time during the year, including during the growing season, which is the part of the year during which rainfall and temperature enhance the growth of plants. ${ }^{5}$ Thus, hydrology largely determines how the soil develops and the types of plant and animal communities respectively living in and on the soil. As such, wetlands may support aquatic and terrestrial species. The prolonged presence of water in delta areas creates conditions that are favourable for the growth and sustenance of specially adapted plants known as 'hydrophytes' and promote the development of characteristic wetland soils, namely hydric soils. ${ }^{6} \mathrm{~A}$ hydric soil is a soil that is formed under conditions of saturation, flooding or ponding long enough during the growing season to develop anaerobic conditions within its upper part. ${ }^{7}$ Consequently, wetlands are areas where the presence of water determines or influences most, if not all, of the biogeochemistry - the biological, physical and chemical characteristics - of such areas. ${ }^{8}$ The amount of water present in a wetland may vary greatly. Some wetlands are permanently flooded, while others are only seasonally or rarely flooded, even though they may retain saturated soils throughout much of the period that is not flooded. Wetlands are complex ecosystems, characterised by specialised assemblage of plants, animals and microbes, as well as flooding or soil saturation, due to fast moving, sluggishly moving or standing water. ${ }^{9}$

Consequently, a wetland should have one or more of the following three attributes: (a) at least periodically, the land predominantly supports hydrophytes; (b) the substrate is hydric soil, which is predominantly not drained; and (c) the substrate is saturated with water or covered by shallow water at some point during wet seasons. There are therefore different types of wetlands, each of which is determined by its hydrology and water chemistry, as well as its component soils and species of plants and animals found or existing in them. ${ }^{10}$ Accordingly, it could be asserted that wetlands exist in every country and in every climatic zone, from the Polar Regions to the tropics, and from high altitudes to dry regions. ${ }^{11}$

\subsection{The True Niger Delta Region versus the Artificial Niger Delta Region}

The true Delta region of Nigeria is distinct from the artificial and politically motivated Niger Delta region

\footnotetext{
${ }^{1}$ Department of Political Science, Niger Delta University (n6), 1.

2 Wetlands International, 'Conserving and Restoring Wetlands in Nigeria's Niger River Delta' $<\underline{\text { https://www.wetlands.org/casestudy/conserving-and-restoring-wetlands-in-nigerias-niger-river-delta/> }}$

Accessed 27 March, 2020; E. T. Bristol-Alagbariya (2010 [n6]) 4.

${ }^{3}$ Wetlands International, 'What are Wetlands' $<$ https://www.wetlands.org/wetlands/what-are-wetlands/> Accessed 27 March, 2020.

${ }^{4}$ Ibid; World Wildlife Fund (WWF), 'Wetlands' < https://www.worldwildlife.org/habitats/wetlands $>$ Accessed 27 March, 2020.

${ }^{5}$ United States Environmental Protection Agency (USEPA), 'What is a Wetland?: Definition of a Wetland' $<$ https://www.epa.gov/wetlands/what-wetland $>$ Accessed 27 March, 2020.

${ }^{6}$ Natural Resources Conservation Service, United States Department of Agriculture, 'Hydric Soils - Introduction' $<$ https://www.nrcs.usda.gov/wps/portal/nrcs/detail/soils/use/hydric/?cid=nrcs142p2 053961> Accessed 27 March, 2020.

${ }^{7}$ Ibid.

${ }^{8}$ The Wetlands Initiative, 'What is a Wetland' $<$ http://www.wetlands-initiative.org/what-is-a-wetland $>$ Accessed March 27, 2020.

${ }^{9}$ C. J. Crandell, 'Wetland' <https://www.britannica.com/science/forest> Accessed 27 March, 2020.

${ }^{10}$ The Wetlands Initiative (n32]).

${ }^{11}$ Wetlands International (n27).
} 
created by the NDDC Act. ${ }^{1}$ Nevertheless, to some extent, the true Niger Delta region and the artificial Niger Delta (created by the NDDC Act) are synonymous. They are synonymous as contemporary oil producing areas of Nigeria. Besides, even the true Niger Delta region is not a homogenous society, as there are certain intrinsic distinguishing factors between and among the region's component ethnic nationalities, tribes, kingdoms and communities. Hence, for instance, on the basis of their geographical location, history and social systems, the ethnic nationalities, tribes, kingdoms and communities of the true Niger Delta region are different. Therefore, this sub-heading will discuss some differences between the true Niger Delta region and the artificial and politically motivated Niger Delta region, as well as consider a basic similarity of these two regions (namely the fact that they are oil producing areas of Nigeria). The study will then proceed to give account of certain internal distinguishing factors and issues within the true Niger Delta region.

Regarding the differences between the true Delta region of Nigeria and the artificial and politically motivated Niger Delta region (created by the NDDC Act), it may be stated that the true Delta region has been distinct from time immemorial. The true Delta region has been ethnographically, historically and geographically distinct, by virtue of its ethnic profile. Based on ethnic configuration, composition and contour, the two regions are distinct and therefore different. On this note, whereas the true Niger Delta region is an ethnic minority region, the rest of the States comprising the artificial Niger Delta region, namely Abia, Imo and Ondo States are basically ethnic majority areas. The exception here is that there are Ijaw ethnic minority oil producing communities and areas of Ondo State. Fundamentally therefore, during the Nigerian Regional era, the people of the oil-rich true Nigerian Delta region were ethnic minorities of the era, which lasted from about 1929 (during the British colonial era) to 1967 (in post-colonial Nigeria [during the Nigerian Civil War, when General Gowon's military regime created the first twelve states of Nigeria, on May 27, 1967). ${ }^{2}$ The people of the oil-rich true Niger Delta belonged to minor ethnic groups and minority of the populace, who were neglected and whose interests were undermined in the Eastern and Western Regions of Nigeria. For instance, some of the people, communities, kingdom and tribes of the true oil-rich Niger Delta region were minorities of the Eastern Region (Eastern Regional Government) and the Western Region (Western Regional Government); whereas, the people of the oil producing areas and communities of Abia and Imo States belonged to the Igbo major ethnic group (the predominant tribe of the Eastern Region and its hegemonic Igbo government: the Eastern Regional Government), in the same manner as the people of the oil producing areas and communities of Ondo State basically belonged to the Yoruba major tribe. The Yoruba ethnic nationality was the dominant ethnic group of the Western Region and its Yoruba-based hegemonic government (the Western Regional Government). On the whole, during the Nigerian Regional era, the interests of the three hegemonic tribes (Hausa-Fulani, Yoruba and Igbo major tribes), as manifested in the plans, policies, programmes and projects, of the Northern, Western and Eastern Regions respectively, and the entire Nigerian polity, prevailed as the law and state-practice of the period. ${ }^{3}$

The true Delta region is known as the Southern Minorities area of Nigeria and presently the South-South geo-political zone of the FRN. Given that Nigeria is presently comprised of six geopolitical zones, the rest of Nigeria's geo-political zones are the North Central zone, North Eastern zone, North Western zone, South Western zone and the South Eastern zone. On the whole, Nigeria is comprised of six geo-political zones, 36 states and their component 774 Local Government Areas (LGAs) as well as the Federal Capital Territory, Abuja, and its six Area Councils. ${ }^{4}$ The Federation has three tiers of government, namely the federal, states, and local governments. Nigeria

\footnotetext{
${ }^{1}$ Section 1 (2) (b), Niger-Delta Development Commission (Establishment Etc.) (NDDC) Act, No. 6 LFN 2000, Cap N86 LFN 2004; Section 4 of the NDDC Act; Section 30 of the NDDC Act; Niger Delta Development Commission (Establishment, Etc.) (NDDC) Amendment Act, 2017; Niger Delta Development Commission (NDDC), Niger Delta Regional Development Master Plan (NDDC 2006) 49-50, 53-55, 60-67.

${ }^{2}$ E. J. Alagoa and A. A. Derefaka (eds) (2002 [n1]), 333; E. T. Bristol-Alagbariya (2010 [n6]), 130 and 134.

${ }^{3}$ O. Nnoli, Ethnic Politics in Nigeria (Fourth Dimension Publishers1980); E. J. Alagoa and A. A. Derefaka (eds) (2002 [n1]), 332-336; S. Azaike, Inequities in Nigerian Politics (Treasure Communications Resource 2003); R. T. Suberu, Ethnic Minority Conflicts and Governance in Nigeria (Spectrum 2003); R. T. Suberu, Federalism and Ethnic Conflict in Nigeria (United States Institute of Peace 2001); E. T. Bristol-Alagbariya, 'Nigeria: The Role of Law in Nation-building' (2016) 1 (1) UNIPORT Journal of Public Law, 113-136, particularly 124-125, 132 and 134.

${ }^{4}$ Section 2, 1999 Constitution of the Federal Republic of Nigeria (CFRN [as amended]), captioned 'The Federal Republic of Nigeria'; Section 3, 1999 CFRN (as amended), 'State of the Federation and the Federal Capital Territory, Abuja'; First Schedule, Part 1, 1999 CFRN (as amended), headed 'States of the Federation: Local Government Area'; First Schedule, Part 11, 1999 CFRN (as amended), captioned 'Definition of Federal Capital Territory, Abuja': 'Federal Capital Territory, Abuja Area Councils'; Central Intelligence Agency (CIA), 'The World Factbook' $<$ https://www.cia.gov/library/publications/the-world-factbook/geos/ni.html > Accessed 27 March, 2020; Worldometers, 'Nigeria Population' $<$ https://www.worldometers.info/world-population/nigeria-population/ $>$ Accessed 27 March, 2020.
} 
is the most populous black African country, having well over 200 million people. ${ }^{1}$ Nigeria's population legend is that 'one out of every five black people on Earth is a Nigerian'. ${ }^{2}$ The country has a land mass of about 923,768 $\mathrm{km} 2$ (i.e., 356,669 sq. miles). It has over 250 ethnic groups including the three major ones, the Hausa-Fulani, Yoruba and Igbo major ethnic groups. Nigeria is, in fact, so tribally, traditionally and culturally diverse in ways that may confuse a foreigner. ${ }^{3}$

Geographically, the true Niger Delta region is bordered to the south by the Atlantic Ocean and to the east by Cameroon. It covers the mouth of the River Niger and the areas to the east and west comprising six major oilproducing States of Nigeria, namely Rivers, Delta, Bayelsa, Akwa-Ibom, Edo and Cross-River States, including the oil-producing areas of Ondo State, which are comprised of citizens of the Ijaw ethnic group. ${ }^{4}$ Conversely, the artificial and politically motivated Niger Delta is made up of the entire nine oil producing States of Nigeria, namely Abia and Imo States and the seven other oil producing States mentioned above, which make-up 185 LGAs of the FRN. ${ }^{5}$ It may be reiterated that petroleum resources development operations commenced in the oil-rich communities of the true Delta region in the late 1950s, which is a period of about three decades, before the development of these resources commenced in such other areas of Nigeria as Abia and Imo States. ${ }^{6}$

Furthermore, in terms of geographical features, the true Delta region of the FRN is mostly a flat, low lying swampy basin criss-crossed by a dense network of meandering rivers, creeks and rivulets, comprising a diverse mosaic of five ecological zones. These ecological zones are the mangrove forest and coastal vegetation zone, the fresh-water swamp forest zone, the low rain forest zone, the derived savannah zone and the montane zone. ${ }^{7}$ Conversely, Abia State and Imo State are remote mainland areas, historically known as parts of the hinterland areas of the true Niger Delta region. ${ }^{8}$

Also, historically, the main occupation of the people of the true Delta region is fishing and seafood gathering, whereas the predominant occupation of the Niger Delta hinterland areas is farming and livestock activities. $^{9}$

Apart from petroleum resources, the true Delta region is a vast sedimentary basin comprised with other mineral resources and natural endowments, such as deltaic deposits like medium to coarse unconsolidated sands, silt, clay, shale and peat. ${ }^{10}$ For instance, Rivers State of the true Delta region is richly endowed with such solid mineral resources as clay, ceramic, sharp sand, gravel, fine sand, glass, coarse sand, grain sand, special stone and laterite. ${ }^{11}$ Outside the true Delta region, other regions, areas and States of Nigeria, such as Abia and Imo States, are endowed with various natural resources. ${ }^{12}$

Concerning similarity, a basic feature of the true Delta region and the artificial Niger Delta region is that they are contemporary oil producing areas or regions of Nigeria. As such, they constitute one of the three major stakeholder groups Nigeria's ongoing petroleum resources development business. ${ }^{13}$ Based on the stakeholder theory of business relations, ${ }^{14}$ the oil-rich Niger Delta and the rest of the oil producing areas of Nigeria (which

${ }^{1}$ World Population Review, 'Nigeria Population 2020' https://worldpopulationreview.com/countries/nigeriapopulation/

${ }^{2}$ S. Odunfa, 'Nigeria's counting controversy' $<$ http://news.bbc.co.uk/2/hi/africa/4512240.stm> Accessed 27 March, 2020.

3 B. N. Onyima, 'Nigerian Cultural Heritage: Preservation, Challenges and Prospects' $<$ https://www.ajol.info/index.php/og/article/viewFile/141270/131004> Accessed 27 March, 2020.

${ }^{4}$ E. T. Bristol-Alagbariya (2010 [n6]), 35-36.

${ }^{5}$ Ibid, 36 .

${ }^{6}$ Ibid.

${ }^{7}$ Ibid; Bonny Joint Industry Committee (JIC) led by NLNG, 'Bonny Kingdom Masterplan | Bonny Island, Nigeria | 2014'<https://www.nleworks.com/case/bonny-kingdom-masterplan/> Accessed 27 March, 2020.

${ }^{8}$ N. Briggs et al (eds) (n2), 61, 64, 69, 87, 92, 104-106 and 108.

${ }^{9} \mathrm{Ibid}, 60-63$.

${ }^{10}$ A. Ogbuigwe, Legal Issues in the Niger Delta Resource Dilemma: A Collection of Essay (Anpez Centre for Environment and Development 2018) 7-10.

${ }^{11}$ Rivers State Ministry of Energy/Natural Resources, whose duty is among others, to 'to identify and develop

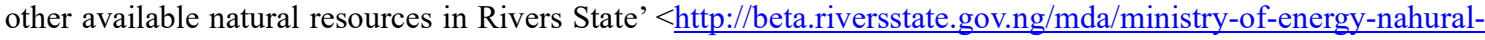
resources/> Accessed 27 March, 2020.

${ }^{12}$ C. Ikenwa (Nigerian Infopedia 2015 - 2020) 'Natural Resources in the 36 States of Nigeria and Locations'

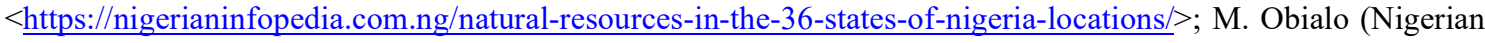
Guide), 'Mineral Resources in Nigeria and their Locations' $<$ https://nigerianguide.com.ng/mineral-resources-innigeria-and-their-locations/>; Nigerian Finder, 'Mineral Resources in Nigeria: the Full List + Locations' $<$ https://nigerianfinder.com/natural-resources-in-nigeria-the-full-list-locations/>; all Accessed 27 March, 2020.

${ }^{13}$ E. T. Bristol-Alagbariya (2010 [n6]) 38-39.

${ }^{14}$ R. E. Freeman, Strategic Management: A Stakeholder Approach (Cambridge University Press 2013); J. F. 
include Abia, Imo and Ondo States) are major stakeholders of Nigeria's petroleum resources development business. The rest of the three major stakeholder groups of Nigeria's petroleum resources development business are the Federal Government of Nigeria, which is represented in the business by the Nigerian National Petroleum Corporation (NNPC), and the oil and gas developing companies operating in the country, led by the Multinational Oil and Gas Companies (MNOCs), otherwise referred to as International Oil Companies or Transnational Companies. ${ }^{1}$

Specifically, concerning the true Niger Delta region, the region is made up of heterogeneous ethnic nationalities. It is also made up of heterogeneous linguistic groups. For instance, there are about 40 different ethnic groups within the region. ${ }^{2}$ Major among these groups are five linguistic groups - the Ijoid, Edoid, Delta Cross, Yoruboid and Igboid groups - each of which is comprised of numerous sub-linguistic groups. Among these five groups, the Ijoid (which has the longest settlement history in the region), is the most complex linguistic group. ${ }^{3}$

Also, there are two main geographical locations of the true Niger Delta region, namely the core or main coastal (essentially saltwater riverine) area and the mainland (upland) area of the region. These two distinct geographical locations have different ethnic nationalities, kingdoms and communities, their respective people and social systems. ${ }^{4}$ The core coastal ethnic nationalities, tribes, kingdoms and communities include Ijaw ethnic nationality, which is the oldest and largest ethnic group of the region. Others are the Ancient Ijaw Kingdoms, City and Trading States, namely Nembe (Brass), Grand Bonny, Opobo Kingdom (which emerged in 1870 from Grand Bonny Kingdom, in the event of the Bonny civil war), Kalabari (New Calabar) and Okrika (Wakrikese). These Ancient Ijaw Trading States, along with the Efik (Old Calabar) and Itsekiri (Warri) Trading States are known as Ancient Niger Delta Trading States, which, from late $15^{\text {th }}$ Century $A D,{ }^{5}$ established foreign relations with the visiting Western European explorers and traders. The foreign relations between these Trading States and their Western European trading counterparts led to the spread of Western European imperialism into the Ancient Niger Delta region, which gave rise to formal British colonialism in the region.

Along with the Ancient Niger Delta Kingdoms and Trading States is their immediate bigger neighbour, Ancient Benin/Edo Kingdom, which also established relations with the Western European imperialists, especially the British. Ancient Benin Kingdom is the immediate bigger neighbour of the Ancient Niger Delta Trading States in the context and framework of the southern ethnic minority nationalities (present-day South-South zone) of Nigeria.

Apart from the Ancient Niger Delta Kingdoms, there are the coastal ethnic nationalities and communities of the true Niger Delta region, whose social system was (and still basically remains) relatively not rigidly centralised. Thirdly, there are the essentially egalitarian mainland ethnic nationalities and communities of the true Niger Delta region. In the Western Delta area, along with the Itsekiri (Warri) Trading State are the Urhobos. From time immemorial, the Ijaws, Itsekiris and Urhobos are the dominant ethnic groups of the Western Delta region. ${ }^{6}$ As is the case in the Western Niger Delta, in contemporary Rivers State of the Eastern Delta, there are the core coastal ethnic nationalities and those of the mainland (upland) areas. ${ }^{7}$ The core coastal nationalities, kingdoms and other forms of communal areas of Rivers State include Kalabari Kingdom, Ibani (comprised of Bonny Kingdom and Opobo Kingdom), Andoni (Obolo), and Okrika; whereas, the upland ethnic groups and communities of the State include Ikwerre, Etche, Ogoni, Ekpeye, Ogba, Abua/Odual and Engenni ethnic nationalities and communities. ${ }^{8}$

Johnston, No Man Can Serve Two Masters: Shareholders versus Stakeholders in the Governance of Companies (The Social Affairs Unit 1998); A. L. Friedman and S. Miles, Stakeholders: Theory and Practice (Oxford University Press 2006); J. S. Andiof et al (eds), Unfolding Stakeholder Thinking: Theory, Responsibility and Engagement (Routledge 2017); J. S. Andiof et al (eds), Unfolding Stakeholder Thinking 2: Relationships, Communication, Reporting and Performance (Routledge 2017); K. Omeje (n6).

${ }^{1}$ E. T. Bristol-Alagbariya (2010 [n6]) 38-39.

${ }^{2}$ Niger Delta Development Commission (NDDC) (n36), 53.

${ }^{3}$ Ibid; E. T. Bristol-Alagbariya (2010 [n6]), 36; E. J. Alagoa and A. A. Derefaka (eds) (2002 [n1]), $149-172$.

${ }^{4}$ E. T. Bristol-Alagbariya, Petroleum Development \& the Environment in Rivers State Nigeria: Fallouts of the UNEP Report on Ogoniland, Environmental Regulatory Standards \& Sustainable Development Laws \& Practices (LAP LAMBERT Academic Publishing 2018), 2.

${ }^{5}$ E. J. Alagoa (2005 [n1]), 80, 117, 124, 138 and 153-155; N. Briggs et al (eds) (n2), 67- 68; E. J. Alagoa and A. Fombo (n8), 7.

${ }^{6}$ O. Ikime, Niger Delta Rivalry: Itsekiri Urhobo Relations and the European Presence, 1884-1936 (Longman 1970); P. O. Okolo et al, 'The Need for Ethnic Integration in the Niger Delta Region of Nigeria: A Focus of Western Niger Delta' [2014] Developing Country Studies, 152-163.

${ }^{7}$ E. T. Bristol-Alagbariya (2010 [n6]), 36.

${ }^{8}$ E. T. Bristol-Alagbariya, Governance Towards Sustainable Development in Nigeria: The Role of Strategic Assessment of Decisions \& Actions (CEPMLP/DUP 2010), 223. 
In the context of this study, social system may be considered as characteristic organisational pattern of ethnic nationalities, kingdom and other forms of communal areas. ${ }^{1}$ The social system of each of the ethnic nationalities, kingdoms and other forms of communal areas of the true Niger Delta region is distinct. From time immemorial, there have been three basic forms of social system practiced by the ethnic nationalities or communal groups of the region. First, in the core or main coastal (fundamentally saltwater riverine) areas of the Eastern Niger Delta, the social system of the City and Trading States was the ward, lineage or house system. ${ }^{2}$ This system has been the social system and pivot of life and society at large in each of the Ancient Eastern Delta Trading States. In the process, each of these States had and still continues to have a centralised system of government, with three principal categories of rulers, namely the Monarchs, Chiefs and Heads of the component lineages of each house. As such, at the apex of house system of governance of each Niger Delta Trading State was and still remains the Amanyanabo (King/Monarch), followed by the subordinate rulers of the Monarch, known as Alapu (Chiefs), some of whom are Amadapu, who were and still remain the subordinate rulers to the Amanyanabo. ${ }^{3}$ There are also major or minor Alapu (Chiefs), depending on the peculiarity of each Ancient Trading State of the region. The subordinate rulers of the Alapu are the Heads of the component lineages of each house. ${ }^{4}$

Second, the earliest social system of the ethnic nationalities or other forms of communal groups inhabiting the coastal area of the Eastern Delta was fundamentally not rigidly centralised as those of the Ancient Trading States of the area. In other words, there are Niger Delta saltwater riverine areas that practised partially politically centralised social system. There were therefore the riverine ethnic nationalities, community groups or communities such as the Andoni (Obolo), which practised a non-core (not rigid) politically social system. ${ }^{5}$ There are also partly saltwater and partly communities or communal groups of the true Niger Delta region such as Abualand (Abua), whose social system is similar to that of such neighbouring areas as Epie-Atissa of the Central Niger Delta, in present-day Bayelsa State. ${ }^{6}$ These are community groups, kingdoms and ethnic nationalities that practised politically centralised social system, as compared with the core centralised social system of the Trading States. Third, there was the essentially egalitarian (republican) form of village democratic social system, exemplified by that of the Ikwerre ethnic nationality of mainland (upland) Niger Delta region. ${ }^{7}$

By and large, the social systems and other internal dynamics of various ethnic nationalities of Ancient Niger Delta region and other peculiarities of these nationalities of the region, such as trade, commerce and foreign relations associated with them, present the region as a distinct area of primordial African civilisation. ${ }^{8}$

\subsection{Primordial Trade, Commerce and Foreign Relations within and Outside Ancient Niger Delta}

Concerning trade, commerce and foreign relations that took place in the primordial era, the core coastal Kingdoms and Trading States (which have fundamentally politically centralised social system) and the relatively not rigidly centralised community groups as well as the predominantly egalitarian mainland (upland) areas exchanged trading commodities and other trading items domestically (within their people). They also exchanged trading items externally (between their people and their neighbours outside their region), and thereby promoted foreign trade, commerce and external relations between the Ancient Niger Delta region and its hinterland areas. ${ }^{9}$ In effect, there were various forms of internal trade and commerce, as well as external trade, commerce and foreign relations within the Delta region. There was also external long-distance trade, commerce and foreign relations between the people of Ancient Niger Delta and their neighbouring primordial areas outside the Ancient Niger Delta. Such external long-distance trade, commerce and foreign relations took place between the people of the Ancient Niger Delta and those of the communities of the Igbo ethnic nationality in the Delta hinterland areas, as well as with more distant ethnic nationalities and areas like Ancient Igalaland in the Middle-belt and primordial Yorubaland in the West. The items of trade of trade and exchange of the people of the coastal Niger Delta ethnic nationalities and communities included such products and items like native salt, fish and other forms of seafood and indigenous fishing gear; besides weaved products, such as basket tray, basket bags, basket traps and basket rafts; pottery and a measure of carved items like art works. Along with these products, those of the coastal

'. T. Bristol-Alagbariya (2010 [n6]), 106-107; F. L. Bates and L. Bacon, 'The Community as a Social System' [1972] 50 (3), Social Forces, 371-379.

2 E. J. Alagoa and A. Fombo (n8), 45, 49, 60-67; E. T. Bristol-Alagbariya (2010 [n6]), 107-110.

${ }^{3}$ E. J. Alagoa and A. Fombo (n8), 6.

${ }^{4}$ E. T. Bristol-Alagbariya(2010 [n6]), 105-110.

${ }^{5}$ Ibid, 126-127.

${ }^{6}$ Ibid, 127-128.

${ }^{7}$ Ibid, 128-129.

${ }^{8}$ K. O. Dike (n5); G. I. Jones (n5); E. J. Alagoa (2005 [n1]); F. Braudel, A History of Civilizations (Penguin Books 1995); P. J. Adler and R. L. Pouwels, World Civilizations (Wadsworth Publishing 2014/Cengage Learning 2015).

${ }^{9}$ N. Briggs et al (eds) (n2), 60-66; E. J. Alagoa, 'Long-Distance Trade and States in the Niger Delta' [1970] 11 (3), The Journal of African History, 319-329. 
Ancestral Ijawland include carved products as canoes, paddles and walking sticks, while cast bronze, carved ivory and other artworks were produced by the Edo (Ancient Benin) people. ${ }^{1}$ On the other hand, the products and items of trade and exchange of the Delta mainland people and communities as well as those of the Igbo hinterland areas were mainly agricultural products, which included livestock like fowls, cows, goats and sheep. Other agricultural products were yam, cocoyam, coconut, banana and plantain. The trade and exchange items of the Igala ethnic nationality of Kogi State in the Middle belt, included iron ore technology items, while those of primordial Yorubaland included the Yoruba traditional hand-woven and dyed cotton clothes such as Ikaki-bite (Cloth of the Tortoise') and those known as Ashoke (aso oke). ${ }^{2}$

The foregoing analysis gives an idea of the nature of trade, commerce and foreign relations that took place within and outside the true Ancient Niger Delta, before the coming of Western European explorers, traders and imperialists from the late $5^{\text {th }}$ Century AD to the Delta region. To a large extent, geographical factors determined the type of goods or trading items produced and supplied by the various primordial people and ethnic nationalities discussed, as well as those received by the people and their respective nationalities in the course of trade, commerce and exchange in the early times (before the $15^{\text {th }}$ Century AD). Accordingly, in the process of their trading relations, geographical factors determined the roles played by each of the trading partners of the true Ancient Niger Delta region. $^{3}$

In the course of history, what followed next in the Ancient Niger Delta region was the arrival of the Western European explorers, adventurers and merchants from late $15^{\text {th }}$ Century AD. The arrival of these European merchants marked the commencement of the Atlantic trade between the Trading States of the Niger Delta and the Western European imperialist nations, represented by their merchants and mercantile groups, such as trading corporations like the United Africa Company and the Royal Niger Company. ${ }^{4}$

\subsection{From the Atlantic Trade in the Niger Delta to the Evolution of Modern Nigeria and Appointment of the Willink Commission in 1957}

This sub-heading of the study would discuss the Ancient Niger Delta region in the context of the Atlantic trade in slaves and forest products and the attendant foreign relations that took place between the Western European imperialist nations and the Niger Delta Trading States, which gave birth to modern Nigeria. The sub-heading would also give account of the appointment of the Willink Commission in 1957, to enquire into the fears of ethnic minority groups of pre-colonial Nigeria and how to allay such fears in the effort towards the attainment of Nigeria's political independence. ${ }^{5}$

It has already been stated that the people of Ancient Niger Delta region, particularly those of the Niger Delta Trading States, were engaged in foreign long-distance trade with their counterparts of Western Europe, who visited the region from the late $15^{\text {th }}$ Century AD. This trade is known as the Atlantic trade. The Atlantic trade in the Niger Delta region robustly took place after the arrival of the Portuguese explorers and merchants, who dominated external relations between the visiting Western European nations and the Trading States of the Niger Delta region. The era after the dominance of the Portuguese in the domain of the Delta Trading States was followed by the prominence of the Dutch merchants, who were dominant in the Delta region in the $17^{\text {th }}$ Century. Thereafter, the French and later on the English merchants and imperialists arrived the Niger Delta region and also became prominent in the affairs of the Trading States of the region. ${ }^{6}$

The Western European merchants and imperialists, who visited the Niger Delta region, especially the British, started to dominate the affairs of the region in the course of the trade, politics and gunboat diplomatic

1 Ibid, 61-66; Stanley Museum of Art, University of Iowa, 'Art \& Life in Africa: Benin Kingdom' $<$ https://africa.uima.uiowa.edu/peoples/show/Benin+Kingdom $>$ Accessed 27 March, 2020.

2 Ndigo Arts Gallery, 'Yoruba Ashoké (aso oke) Cloth from Nigeria' < https://indigoarts.com/galleries/yorubaashok-aso-oke-cloth-nigeria $>$ Accessed 7 March, 2020; Bellafricana, 'The History of Aso-Oke Textile' $<$ https://bellafricana.com/the-history-of-aso-oke-textile/> Accessed 27 March, 2020; E. J. Alagoa (1970 [n70]), 319-329; E. J. Alagoa and A. Fombo (n8), 6; M. G. Anderson and P. M. Peek (eds), Ways of the Rivers: Arts and Environment of the Niger Delta (Regents of the University of California 2002), 251-267; N. Briggs et al (eds) (n2), 61-66.

${ }^{3}$ N. Briggs et al (eds) (n2), 61-66.

4 Ibid, 67-85; Encyclopaedia Britannica, 'Royal Niger Company: British Company' $<$ https://www.britannica.com/topic/Royal-Niger-Company $>$; Encyclopedia.com, 'Royal Niger Company'

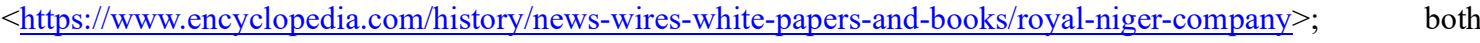
Accessed 27 March, 2020; J. E. Flint, Sir George Goldie and the Making of Nigeria (Oxford University Press 1960).

${ }^{5}$ The Willink Commission, NIGERIA Report of the Commission Appointed to Enquire into The Fears of Minorities and The Means of Allaying Them (Her Majesty's Stationery Office [HMSO] 1958).

${ }^{6}$ E. J. Alagoa (2005 [n1]), 80, 117, 124, 138 and 153-155; N. Briggs et al (eds) (n2), 67-85, particularly 67-68. 
activities that took place in the region, its mainland areas and the Delta hinterland areas as well as other ethnic nationality areas of pre-colonial Nigeria, which were subsequently politically amalgamated to form modern Nigeria. The British gunboat diplomacy in the Niger Delta region and the rest of pre-colonial Nigeria was Great Britain's foreign policy that was supported by the use or threat of military force in the pre-colonial Nigerian areas with which the British imperialists had direct contact and thereby established unequal relations with these areas. ${ }^{1}$

The first form of Atlantic trade was the trade in humans (slave trade), which took place between the $15^{\text {th }}$ and the $19^{\text {th }}$ Centuries. The slave trade was formally outlawed in the $19^{\text {th }}$ Century, by virtue of the landmark judgment of Lord Mansfield in the Somerset's Case (Summerset v Stewart). ${ }^{2}$ The slave trade was followed by the trade in agricultural (forest) products, particularly oil palm produce. Whereas during the slave trade, the Western European trading nations only had contract and relations with the Niger Delta Trading States; during the trade in forest products, otherwise called legitimate trade (when slave trade was outlawed), the European trading nations had established direct contact and relations with the Niger Delta mainland and hinterland forest products producing areas. Thus, whereas the Trading States basically occupied a middleman position in the course of the Atlantic slave trade; during the Atlantic trade in forest products, the Western European merchants, backed by their respective nations, undermined the middleman position of the Niger Delta Trading States. In the process, the British merchants, backed by Great Britain, crippled the middleman position of the Trading States, and thereby established direct relations with the Niger Delta mainland and hinterland producers of forest products required by Great Britain. $^{3}$

The British imperialists penetrated into the Niger Delta mainland and hinterland areas through entering into negative treaty relations with the Niger Delta Trading States. For instance, the British treaties of friendship, trade and commerce, which the British imperialists entered into with some of the Niger Delta Trading States, such as those of the Eastern Delta, were negative sovereignty treaties. ${ }^{4}$ These negative sovereignty treaties enabled Great Britain to establish its imperialist interest in the Niger Delta region over and above the interest of other competing Western European imperialist-nations at the Berlin West African Conference of 1884/1885, during the scramble and partition of Africa among these imperialists. ${ }^{5}$ Beginning with the 1961 British negative sovereignty treaty with King Dosunmu of Lagos, Lagos became a Colony and Protectorate of Great Britain, ${ }^{6}$ the British imperialists made incursions into the rest of primordial ethnic nationality areas, which eventually constituted modern Nigeria. From the context and groundwork of the Niger Delta region, based on the 1884 Treaties of friendship, peace, commerce and protection with the Niger Delta Trading States, ${ }^{7}$ Great Britain established a Colonial Protectorate over the entire Niger Delta region and its Igbo hinterland areas. By virtue of these treaties, the British consolidated on its friendship with the Trading States and to ensure peace and smooth process of trade and commerce in the region, where the trading States were engaged in cut-throat struggle and incessant battles against themselves, so as to protect their middleman position in the course of the Atlantic trade. These negative sovereignty treaties provided a platform for Great Britain to establish a colonial protectorate over the entire Niger Delta region and its mainland and Igbo hinterland areas, and thereby began to have direct relations with the

${ }^{1}$ E. J. Alagoa et al (eds) (2009 [n1]); 379, 398 and 481; N. Briggs et al (eds) (n2), 76 and 84; J. Cable, Gunboat Diplomacy (Palgrave Macmillan 1994); S. Jaja and E. A. Jaja, Aspects of British Gunboat Diplomacy -Jaja King of Opobo (BMO Publishing 2015); Urhobo Historical Society, 'British Colonial Rule in the Niger Delta "Treaties of Protection"”

$<$ http://waado.org/UrhoboHistory/NigerDelta/ColonialTreaties/EditorsIntroduction/EditorsIntroduction.html $>$ Accessed 27 March, 2020.

${ }^{2}$ Somerset v Stewart [1772] 98 ER 499; S. M. Wise, Though the Heavens May Fall: The Landmark Trial That Led to the End of Human Slavery (Da Capo Press 2006); N. S. Poser, Lord Mansfield: Justice in the Age of Reason (McGill-Queen's University Press 2013); Federal Republic of Nigeria, Nigeria at 50: A Compendium: The Official and Authoritative Book about Nigeria (Published on the Golden Jubilee Independence Anniversary www.1stoctober.com Publishing 2010), 27-28.

${ }^{3}$ N. Briggs et al (eds) (n2), 83 .

${ }^{4}$ G. I. Jones (n5), 243-245, item 11, captioned 'Treaty between Great Britain and New Calabar, 1884'.

${ }^{5}$ S. Forster et al (eds), Bismarck, Europe and Africa: The Berlin Africa Conference, 1884-85, and the Onset of Partition (Oxford University Press 1989); T. Pakenham, The Scramble for Africa (Abacus 1992/2003); Charles River Editors, The Scramble for Africa: The History and Legacy of the Colonization of Africa by European Nations during the New Imperialism Era (Charles River Editors 2017).

${ }^{6}$ E. Stehr, Interesting History of Lagos [Nigeria] (CreateSpace Independent Publishing Platform 2016).

${ }^{7}$ G. I. Jones (n5), 243-244; E. T. Bristol-Alagbariya, 'The Validity and Enforceability of the Oil Rivers Treaties of Protectorate' [1990] dissertation submitted to the Faculty of Law, Rivers State University of Science and Technology, in partial fulfillment of the requirements for the award of the Degree of Bachelor of Laws (LLB); A. Oyebode, 'Treaties and the Colonial Enterprise: The Case of Nigeria' [1990], 2 (2) African Journal of International and Comparative Law, 17-36. 
mainland and hinterland producers of forest products. ${ }^{1}$

The British negative sovereignty treaty-relations with the Ancient Niger Delta Trading States marked the end of the primordial sovereign statehood of these Trading States as well as the natural political independence of the neighbouring areas and hinterland areas of these Trading States that Great Britain incorporated into its Colonial Protectorate of Niger Districts in 1885. Eventually, the British Colonial Protectorate of Niger Districts was renamed the Oil Rivers Protectorate in 1889, and thereafter the Niger Coast Protectorate in 1893. The entire Niger Delta region and its Igbo hinterland areas subsequently became a part and parcel of the Colony and Protectorate of Southern Nigeria in 1890, which was ultimately politically amalgamated with the Colony and Protectorate of Northern Nigeria to form the Colony and Protectorate of Nigeria (modern Nigeria) in 1914. ${ }^{2}$ So, consequent upon the Atlantic trade in slaves and forest products and the pattern of Great Britain's' foreign relations known as British gun-boat diplomacy in primordial Niger Delta region and the rest of pre-colonial Nigeria, Great Britain introduced formal colonialism over the domains of the entire pre-colonial Nigerian tribes and areas, which were politically amalgamated to form modern Nigeria. This was how modern Nigeria came into existence, by Great Britain's appointment of Lord Frederick Lugard as the Governor General of the British Colony and Protectorate of Nigeria in $1914 .^{3}$

Formal British colonialism (which commenced in 1914), led to the introduction of regional governments (otherwise called Regionalism) in British-colonial Nigeria. Regionalism thrived from about 1939 (in Britishcolonial Nigeria) to 1967 (in post-colonial Nigeria). ${ }^{4}$ During the Regional era, Nigeria's three hegemonic ethnic groups, namely the Hausa-Fulani, Yoruba and Igbo tribes, and their leaders dominated Nigeria's politics and process of nation-building in their favour, to the detriment of the ethnic minorities (minor tribes) of the country. At the time, the leaders of the three major tribes and premiers of their respective Regions, Sir Ahmadu Bello (the Sardauna of Sokoto), Chief Obafemi Awolowo and Dr Nnamdi Azikiwe, were the live-wire of the three dominant political parties in the three Regions of Nigeria, namely the Northern, Western and Eastern Regions. Respectively, these political parties were the Northern People's Congress (NPC, 1951-1966), the Action Group (AG, 1950-1966) and the National Council of Nigeria and the Cameroons (NCNC, 1944-1966). Although each of these political parties had national (countrywide) objectives in varying degrees, the interests of the three major hegemonic ethnic groups remained paramount in their affairs. Thus, as indicated above, the wishes and aspirations of the three dominant ethnic groups prevailed in their respective Regions and the entire Nigerian polity. ${ }^{5}$

The foregoing state of affairs aroused the interest of ethnic minority groups, which include those of the Niger Delta region. At the time, the ethnic minority groups of the Niger Delta region were within the Western Region and the Eastern Region, which were respectively dominated by the Yoruba major ethnic group and the Igbo ethnic group. In reaction to the domineering attitude and practices of the three major ethnic groups, the ethnic minority groups had to initiate political movements and struggles for fair-play in Nigeria. For instance, while in the Rivers Province of the Niger Delta, which was under the Eastern Region, Chief H. J. R. Dappa-Biriye formed and headed the political party known as the Niger Delta Congress (NDC), in the Northern ethnic minority MiddleBelt area, the Middle-Belt Congress (MBC) was accordingly formed and led by Joseph Tarka. ${ }^{6}$

In the Nigerian Regional era, during the Nigerian Independence Constitutional Conferences (NICCs), which commenced in Lagos-Nigeria, in 1953/54, and ended at Lancaster House Conferences in London, between 1957 and 1958, the agitation of the ethnic minority groups became more pronounced and attracted the sympathy of the British colonial government. The ethnic minority groups agitated for domestic autonomy in British Colonial Nigeria, towards and within post-colonial Nigeria. In the Eastern Region, the ethnic minority groups organised themselves into two movements for the creation of two States from the Region. These are the more-embracing movement for the creation of the Calabar, Ogoja and Rivers (COR) State from the Calabar, Ogoja and Rivers

\footnotetext{
${ }^{1}$ N. Briggs et al (eds) (n2), 84 .

${ }^{2}$ E. J. Alagoa and A. A. Derefaka (eds) (2002 [n1]), 324-326; E. T. Bristol-Alagbariya (2010 [n6]), 130; J. C. Anene, Southern Nigeria in Transition 1885-1906: Theory and Practice in a Colonial Protectorate (Cambridge University Press 2009); M. Crowder, The Story of Nigeria (Faber and Faber 1978), 188-206.

${ }^{3}$ F. J. Lugard, 'Lugard in Nigeria: Report on the Amalgamation of Northern and Southern Nigeria and Administration, 1912-1919' (Unpublished Reports of Library of African Study: Routledge 2004).

${ }^{4}$ E. J. Alagoa and A. A. Derefaka (eds) (2002 [n1]), 333; E. T. Bristol-Alagbariya (2010 [n6]), 52-53, 130 and 134.

${ }^{5}$ E. J. Alagoa and A. A. Derefaka (eds) (2002 [n1]), 332-336; S. Azaike (n38); R. T. Suberu (2003 [n38]); R. T. Suberu (2001 [n38]); E. T. Bristol-Alagbariya (2016 [n38], 113-136, especially 124-125, 132 and 134; O. Ikime (ed) (Historical Society of Nigeria), Groundwork of Nigerian History (Heinemann Educational Books (Nigeria) 2004), 410-481.

${ }^{6}$ E. J. Alagoa and A. A. Derefaka (eds) (2002 [n1]), 342 and 345; A. Etekpe, et al, Harold Dappa-Biriye: His Contributions to Politics in Nigeria (Onyoma Research Publications 2003), 54-57 and 195-243; P. Brass (ed), Ethnic Groups and the State (Croom Helm 1985).
} 
(COR) Provinces of the Eastern Region as well as the less-embracing movement for the creation of a Separate Rivers State from the Rivers Province (made up of Port Harcourt, Ahoada, Brass, Ogoni and Degema [PABOD] Divisions) of the Eastern Region. ${ }^{1}$

Considering the seriousness of the plight and predicaments canvassed by the ethnic minorities and their fears of continuous marginalisation, neglect and subjugation by the three dominant ethnic groups in emergent postcolonial Nigeria, the departing British colonial government decided to take immediate action. The colonial government did so by abruptly adjourning the 1957 NICC, which took place at the Lancaster House in London, and appointed a Commission to address the concerns of the minorities. This Commission, chaired by Sir Henry Urmston Willink, is popularly known as the Willink Commission. ${ }^{2}$

Sir Henry Willink, the Chairman of the Commission, was a British Queen's Counsel, politician, public servant and former Vice Chancellor of Cambridge University. The Willink Commission was mandated to enquire into the fears of ethnic minority groups and how to allay such fears towards the grant of political independence to Nigeria as well as within post-colonial Nigeria. ${ }^{3}$

\section{Niger Delta in Modern Nigeria: From the Willink Commission Report and Commencement of Petroleum Development in 1958 to Niger Delta Development Commission (NDDC) Act of 2000}

This sub-heading is divided into the following divisions: 'From the Willink Commission Report of 1958' and 'Commencement of Petroleum Development in 1958 to Niger Delta Development Commission (NDDC) Act of 2000 '.

\subsection{The Willink Commission Report of 1958}

Briefly put, for five weeks, between November and December, 1957, the Willink Commission organised sessions in more than six centres covering the Eastern, Western and Northern regions, to receive memoranda and collate other forms of complaints from the minorities. ${ }^{4}$ Thereafter, the Commission prepared its report and submitted same to the British Colonial Office in 1958. The Commission's report was submitted to the Colonial Office between April and July, 1958, from where it passed through the Office of the Secretary of State for the Colonies, to the British Parliament. Consequently, the next and last NICC, referred to as the resumed NICC, took place in September 1958, at the Lancaster House in London. ${ }^{5}$

During its relatively short period of assignment, the Willink Commission realised and appreciated the concerns, fears and plight of the ethnic minorities. Thus, with regard to the Delta ethnic minority groups within the Eastern and Western regional governments at the time, the report of the Commission precisely described the Delta region as 'poor, backward, and neglected'. ${ }^{6}$ The report, while describing the pitiable state of the environment in the Delta region and the attendant difficulties confronting citizens of the region, states as follows:

We were impressed by arguments indicating that the needs of those who lived in the creeks and swamps of the Niger Delta are very different from those of the interior. We agree that it is easy for a Government or Legislature operating from the far inland to concern itself, or even fully understand, the problems of a territory where communications are so difficult, building so expensive and education so scanty. ${ }^{7}$

Members of the Willink Commission concluded that:

.. . we had no doubt that a feeling of neglect and a lack of understanding was wide-spread in both Regions (Western and Eastern Deltas). We consider that a case has been made out for special treatment of this area. This is a matter that requires special effort because it is poor, backward and neglected. ${ }^{8}$

However, after its in-depth investigation of the fears and concerns of the ethnic minorities, the Willink Commission only made partial and palliative recommendations aimed allaying the plight of the minority ethnic

\footnotetext{
${ }^{1}$ A. Etekpe et al (n89), 30-33; E. J. Alagoa and A. A. Derefaka (eds) (2002 [n1]), 331-350; E. T. Bristol-Alagbariya (2010 [n6]), 51-57.

${ }^{2}$ M. T. Akobo et al (Southern Minorities Movement)/The Willink Commission, NIGERIA Report of the Commission Appointed to Enquire into The Fears of Minorities and The Means of Allaying Them (Southern Minorities Movement [SMM] [reprint] 1996).

${ }^{3}$ M. T. Akobo et al (Southern Minorities Movement) (n91), 5-6 and back cover preview; O. Ikime (ed) (Historical Society of Nigeria) (n88), 393-409.

${ }^{4}$ Ibid, iii and back cover preview.

${ }^{5}$ E. T. Bristol-Alagbariya (2010 [n6]), 53; U. Udoma, History and the Law of the Constitution of Nigeria (Malthouse Press 1994), 195-238.

${ }^{6}$ M. T. Akobo et al (Southern Minorities Movement) (n91), 5-6 and back cover preview; O. Ikime (ed) (Historical Society of Nigeria) (n88), ii and 94.

${ }^{7}$ Ibid.

8 D. S. P. Alamieyeseigha, 'The Environmental Challenge of Developing the Niger Delta', $<$ http://www.gasandoil.com/goc/news/nta40214.htm $>$ Accessed 17 February, 2016.
} 
groups. So, rather than recommending for the creation of States for the minority ethnic groups that canvassed for the creation of States before the Commission, the Commission made recommendations for safeguards in the Nigerian Independence Constitution to allay the fears of the minority tribes to accept political independence along with the dominant ethnic groups. For instance, in the Delta region, it made recommendation for the Delta region to be designated as a 'Special Area', to be developed with a physical developmental Board. By so making recommendation for measures that are considered by the ethnic minorities as merely partial and palliative, the Commission wrongly assumed that the problems of the ethnic memories would be allayed on Nigeria's attainment of political independence under a politically united Nigeria. The Willink Commission assumed that its report would be implemented in post-colonial Nigeria. The Commission assumed that years of concerted nation-building in terms of development projects - physical, manpower and industrial, would bring the minority tribes into the mainstream of federalism and democracy in post-colonial Nigeria. In the case of the Niger Delta region, the Willink Commission report provides as follows:

ten years of concerted development projects - physical, manpower and industrial, would bring the people of the region into the mainstream of federalism and democracy in post-colonial Nigeria. ${ }^{1}$

However, the assumption of the Willink Commission turned to be wrong, as several aspirations and recommendations of the Commission, which were adopted in the process of the NICCs, are not eventually implemented in post-colonial Nigeria. The non-implementation, which continued to foster the nest of the three hegemonic ethnic groups in post-colonial Nigeria, is, among other factors, due to the lopsided process of nationbuilding that continues to oppress, suppress and repress the ethnic minorities of the country. ${ }^{2}$

After the submission of the Willink Commission report and following the Commission's recommendation for the Delta region to be designated as a 'Special Area', to be developed with a physical developmental Board, the Niger Delta Development Board (NDDB) was set-up in 1961. ${ }^{3}$ The Board was directed to initiate schemes to supplement the normal development of the Delta region. The Board became moribund institution after the Nigerian Civil War of 1967-1970, its activities were frustrated by the FMG. ${ }^{4}$ The FMG neglected the rationale upon which the NDDB was established as well as other interests of the people of the Delta region. Ironically, in due course, based on the developmental philosophy on which the Board was established, in 1976 the FMG, led by General Olusegun Obasanjo, established the River Basins Development Authorities' (RBDA) system, by virtue of the River Basins Development Authorities Act (RBDAA). ${ }^{5}$ In the process, the FMG created ten more RBDAs in other parts of the federation, and changed the name of the NDDB to the Niger Delta River Basin Development Authority (NDBDA). Under the RBDA system, the NDBDA was undermined, as it was starved of funds, while most of the other ten RBDAs were generously funded by the Government. ${ }^{6}$

\subsection{Petroleum Development and the Niger Delta Development Commission (NDDC) Act}

It may be cogent to start this sub-heading by giving account of how petroleum development operations commenced in the communities of the oil-rich Niger Delta region in 1958, up to the period of the enactment of the Niger Delta Development Commission (NDDC) Act in 2000.

\subsection{Commencement Petroleum Development in 1958 to Niger Delta Development Commission (NDDC) Act of 2000}

The search for crude-oil in Nigeria commenced in 1908, during the British colonial era, by the exploration activities of the Nigerian German Bitumen Company at Araromi, in Ondo State. Although, the company did not

\footnotetext{
${ }^{1}$ M. T. Akobo et al (Southern Minorities Movement) (n91), ii.

${ }^{2}$ Ibid, 5- 6 .

${ }^{3}$ Ibid, 94-95.
}

${ }^{4}$ E. T. Bristol-Alagbariya (2010 [n6]), 54-56; Southern Minorities Movement, Roots, the Struggle and the Future (Southern Minority Movement 1995); Southern Minorities Movement, Appraisal of the Nigerian Crisis and Solution (Southern Minority Movement 1995); Southern Minorities Movement, What All Southern Minorities Must Know (Southern Minority Movement 1995).

${ }^{5}$ River Basins Development Authorities Act, Cap R9 LFN 2004; A. T. Ogundele, A. T., 'River Basin Development Authorities in Nigeria: The Neglected Tools for National Development' [2019] 5 (3), International Journal of Advanced Academic Research: Sciences, Technology and Engineering, 39-49; A. J. Adegeye, 'Establishing River Basin Development Authorities as a Strategy for Nigerian Rural Development' [1982] 9 (4) Agricultural Administration, 301-311; C. J. Barrow, 'River Basin Development Planning and Management: A Critical Review. [1998] 26 (1) World Development, 171-186.

${ }^{6}$ E. T. Bristol-Alagbariya (2010 [n6]), 58-64; The Guardian Newspapers, 'Niger Delta Basin Authority gets new office complex' <https://guardian.ng/property/niger-delta-basin-authority-gets-new-office-complex/> Accessed 27 March, 2020. 
succeed in making any discoveries and had to stop due to the outbreak of the First World War, very extensive bitumen deposits have now been discovered in the area of its exploratory activities. Crude-oil exploration activities continued in 1938, when Shell D'Arcy Petroleum Development Company, owned by the British and the Dutch, was granted concession over the entire mainland of Nigeria. Consequently, Shell D'Arcy Petroleum Development Company, which in 1956 changed its name to Shell-BP Petroleum Development Company of Nigeria Limited, made the first discovery of crude-oil in commercial quantities on Sunday, 15 January, 1956, at Otuabagi, in the Colonial Oloibiri District of present-day Bayelsa State. This discovery site was however named the Oloibiri oilfield. The Shell-BP Petroleum Development Company of Nigeria Limited (now known as the Shell Petroleum Development Company of Nigeria Limited [SPDC/Shell Nigeria]) commenced crude-oil production in 1958. In the process, petroleum development operations started in the oil producing communities of the region in $1958 .{ }^{1}$

Also in the process of petroleum development operations, Shell Nigeria laid its first crude-oil pipeline from the Oloibiri oilfield to Port Harcourt and onto the Bonny River, where the Bonny crude-oil terminal is situated. Shell's operational activities at the Shell Bonny Crude-Oil Terminal (i.e., BCOT - now known as the Bonny Oil and Gas Terminal, BGOT) started in 1957/58, consequent upon which the terminal was commissioned in 1961, for the crude-oil export to oversees consumer-nations and public. ${ }^{2}$

Soon after the commencement of petroleum resources development operations in the oil producing communities of the oil-rich Delta region, the resources development operations began to generate adverse consequences on the environment, people and communities of the region. Various adverse consequences of the resources development operations in the Delta region and other oil-producing areas of Nigeria may be divided into environmental, socio-economic and political consequences. These consequences and challenges include lack of genuine participation of the citizens and citizen-groups in the course of resources development operations in their communal homelands. ${ }^{3}$ Other adverse consequences and challenges include ineffective development projectslevel Environmental Assessment, namely Environmental Impact Assessment, lack of life-cycle assessment of petroleum development projects and non-existence of Strategic Environmental Assessment in Nigeria. There are also such adverse consequences and challenges of these resources development operations as negative health impacts, human rights violations, degradation, devastation and despoliation of the environment, ecology and ecosystems, as well as deterioration of ecosystem services in the oil-rich Delta region ${ }^{4}$ and other oil producing areas of Nigeria. ${ }^{5}$

About the end of the Nigerian Civil War in 1967 onwards and more aggressively early 1990s, citizens and citizen-groups of the minority ethnic groups of the oil-rich ethnic minority Delta region had begun to agitate against the adverse consequences of petroleum development operations in their communities and the entire region. They realised that such benefits of the struggle of the minority ethnic groups such as series of states creation exercises, the regime of the River Basins Development Authorities (RBDAs) and various revenue allocation formulas in the country, have in the course of nation-building been manipulated in favour of the three hegemonic tribes in the country. For instance, the Federal Government (FG), systematically and drastically reduced the revenue-allocation formula based on the principle of derivation to the detriment of the Delta region's oil-producing ethnic minorities. Revenue derivable under the nation's principle of derivation was reduced from 50 per cent (at

${ }^{1}$ E. J. Alagoa et al (eds), History Concourse 2011: The Niger Delta Environment as Resource and Reserve (Onyoma Research Publications 2012), 223-224.

${ }^{2}$ Shell Nigeria, 'The History of Shell in Nigeria' $<$ https://www.shell.com.ng/about-us/shell-nigeria-history.html $>$; Shell Nigeria, 'SPDC - Shell Petroleum Development Company of Nigeria' https://www.shell.com.ng/aboutus/what-we-do/spdc.html > both Accessed 27 March, 2020; L. Barrett, 'Niger Delta: The True Story' [2008] 468 January, New African Magazine, 12-20; E. J. Alagoa et al (eds) (2012 [n104]), 223-225.

3 D. S. P. Alamieyeseigha, 'The Environmental Challenge of Developing the Niger Delta' $<$ http://www.gasandoil.com/news/africa/dc25fd9a4f269db32cbd840c81556edb $>$ Accessed 5 October, 2019; E. J. Alagoa et al (eds) (2012 [n104]), 217-267; A. Ogbuigwe, Offended: Legal Issues in the Niger Delta Struggle (Anpez Centre for Environment and Development 1999) especially 2-43 and 187-193; A. A. Ikein (n6); R. Cui, Oil Multinationals in Nigeria Human Rights, Sustainable Development and the Law (Anchor Academic Publishing 2015); A. Manirabona and Y. V. Cárdenas, Extractive Industries and Human Rights in an Era of Global Justice: New Ways of Resolving and Preventing Conflicts (LexisNexis Canada 2019); O. Oluduro, 'Oil Exploitation and Human Rights Violations in Nigeria's Oil Producing Communities' [2012] 25 (2) Afrika Focus, 160-166; Wiwa v Shell Petroleum Development Company of Nigeria Limited (SPDC), 04 Civ. 2665, (SDNY); Wiwa et al. v Royal Dutch Petroleum Company, et al., Case No. 96 Civ. 8386 (KMW) (HBP) (Southern District of New York [SDNY]); Ken Wiwa et al. v Brian Anderson et al., Case No. 01 Civ. 1909 (KMV) (HBP) (SDNY); Kiobel v Royal Dutch Petroleum Company [2013] US 133 S Ct. 1659; Gbemre (Jonah Gbemre) v The Shell Petroleum Development Company Nigeria Ltd. \& 2 Ors [2005] FHC/B/CS/53/05).

${ }^{4}$ United Nations Environment Programme [UNEP], Environmental Assessment of Ogoniland (UNEP 2011).

${ }^{5}$ A. Ogbuigwe (n102). 
the time of political independence) to 0 per cent and 3 per cent, for the oil producing States of the Delta region. ${ }^{1}$ Also, several other FG's institutions continue to operate in ways that neglect and undermine the interest of the Delta region, so as to equitably develop the region. Also, in order to address the plight and predicaments of the oil producing areas, particularly the oil-rich ethnic minority Delta region, one of the bold strides taken by the FG, during the era of the FMG, led by General Ibrahim Babangida, was to promulgate the Oil Mineral Producing Areas Development Commission Decree (OMPADEC) Decree, Decree No. 23 of 1992. This Decree established OMPADEC, to cater for the rehabilitation and development of oil mineral producing areas and to tackle ecological and generic environmental problems associated with petroleum resources development operations. Thus, OMPADEC was established to physically and economically develop and rehabilitate the oil-rich Delta region, and to make a better impact in the region than its predecessor, the defunct NDDB. ${ }^{2}$ Ironically, OMPADEC ended up not achieving its goals before it came into extinction in 1996. OMPADEC did not achieve its goals, more so due to several unfinished development projects and non-payment of contractors who were awarded development projects to execute in the oil-producing areas. Like the NDBRDA, among other reasons that led to its demise is the fact that OMPADEC was starved of funds by the FG which could not sustain its political will and commitment to ensure the continued existence of OMPADEC. For instance, whereas between 1992 and 1995, the OMPADEC received N11 billion from the FG, the Petroleum (Special) Trust Fund (PSTF), (which many believe was again politically set up by the FG as were the ten other River Basin Development Authorities in 1976) received N346 billion from the government between 1994 and $1997 .{ }^{3}$ Most citizens of the Delta region were thus not in doubt that the dissolution of the OMPADEC was not enhanced by the setting up of the PSTF, which undermined the interest of the Niger Delta region and thereby neglected the development of the region.

By the second half of the 1990s, due to about four decades of petroleum resources development operations in the Delta region, the plight of the people and communities of the region had become more deplorable, poorer, neglected and underdeveloped, than the findings of the Willink Commission of Enquiry. In other words, the deplorable state of the Delta region and the plight of its people demonstrate that they are worse than what obtained during the period of the Willink Commission, due to the same historical problem; which is, the marginalisation of the interests of the region and its people by the major tribes whose elites control political power and authority, and in effect decision-making and decision-implementation processes in Nigeria.

It became obvious to the minority ethnic groups of the Delta region that various intervention measures of the FG aimed at addressing the age-old problems and continuing challenges of the Delta region were partial and palliative. The people of the Delta ethnic minority region realised that efforts of successive FGs, since the preindependence era of Nigeria, have made no appreciable impact on the lives of the people of the Delta region, considering that such efforts have not addressed the marginalisation and underdevelopment of the region. Citizens and citizen-groups of the Delta ethnic minority region began to strengthen their quest for fair-play, equity and social justice in Nigeria. In the process, citizens and citizen-groups of the region began to make declarations, demands and other forms of pronouncements concerning the adverse consequences of petroleum resources development operations in their communities as well as their positions on the way forward. These pronouncements include the Ogoni Bill of Rights of 1990, the Endangered Environment of the Niger Delta of 1992, the Kaiama Declaration of 1998, the Resolution of the First Urhobo Economic Summit, the Warri Accord, the Aklaka Declaration of the Egi People, the Oron Bill of Rights, the Demand of the First Niger Delta Indigenous Women's Conference for Women of Bayelsa State, the Ikwerre Rescue Charter, the Declaration of the Niger Delta Bill of Rights, and other related declarations and demands of other citizen-groups of the region. Also, some of these civil society groups made up of militant youngsters formed various militant movements, which include the Niger Delta People's Volunteer Force, Niger Delta Liberation Front, Movement for the Emancipation of the Niger Delta, Niger Delta Vigilante and the Bakassi Movement for Self-Determination. A common agenda underlining the declarations, pronouncements and demands of the communities and civil society groups of Rivers State and those of other parts of the ethnic minority Delta region is the issue of 'resource control' ${ }^{4}$ which is associated with fiscal federalism in Nigeria. ${ }^{5}$ To address the age-long problems of neglect and marginalisation that translated into youth restiveness, aggravated by militancy in the oil-rich Delta region, which was disrupting smooth petroleum resources development operations in the oil-producing communities of the region, the FG, led by President Umaru Musa Yar'Adua (May 2007 - May 2010), initiated the ongoing Presidential Niger Delta Amnesty programme in

\footnotetext{
${ }^{1}$ Ibid, 19-20.

${ }^{2}$ A. K. Horsfall, The OMPADEC Dream (Inprint Publications 1999), 5.

${ }^{3}$ Ibid.

${ }^{4}$ O. V. C. Okene (ed), Readings in Law and Policy (Current Issues and Trends): (In Commemoration of the Golden Jubilee of Rivers State (1967-2017) (Faculty of Law, Rivers State University 2017) 129-144; E. T. BristolAlagbariya (2010 [n6]), 40-43; A. Ogbuigwe (n49).

${ }^{5}$ Ikein A. A. and Briggs-Anigboh C., Oil and Fiscal Federalism in Nigeria: The Political Economy of Resource Allocation in a Developing Country (Ashgate Publishing 1998).
} 
2009/2010. This programme was consolidated upon by the succeeding FG led by President Goodluck Jonathan (February 2010 - May 2015) up to the continuing administration of President Muhammadu Buhari (May 2015 Present). ${ }^{1}$

The consequences and challenges are worsened by the unitary nature and practices of the FRN, and particularly lack of government social responsibility (GSR) in the federation. ${ }^{2}$ Eventually, from the 1990 s, the increasing adverse consequences of petroleum development operations to give rise to community crises, unrest and violent conflicts, aggravated by youth restiveness and militancy, in the oil producing communities of the true Delta region. ${ }^{3}$

Due to worsening consequences of petroleum development operations in the oil-rich ethnic minority Delta region, the region became crises-ridden ${ }^{4}$ and an endangered region; perhaps, the most endangered Delta region in the world. ${ }^{5}$ The state of the endangered oil-rich Niger Delta region became more deplorable because of the absence of GSR and lack of corporate social responsibility (CSR) measures, particularly social responsibility measures of MNOCs operating in the region. ${ }^{6}$ Citizens and citizen-groups of the Niger Delta region thus decried that their region is both a goldmine and pathetic region of Nigeria due to the paradoxes associated with unsustainable petroleum resources development operations. They lamented that these unsustainable operations taking place in the region amount to political and economic neglect, marginalisation, deprivation, as well as environmental degradation, devastation and despoliation, generating poverty in the midst of plenty and thereby undermining the general wellbeing of the oil-rich communities, citizens and future generations of the region. ${ }^{7}$

It has already been indicated that a common subject-matter of the agitation of the citizens and citizengroups of the region is the issue of 'resource control', which is associated with fiscal federalism in Nigeria. The

${ }^{1}$ E. T. Bristol-Alagbariya (2013 [n61]), 218-261, 268 and 271-276.

2 E. T. Bristol-Alagbariya, 'Duties in Permanent Sovereignty over Natural Wealth and Resources and Petroleum Development in Nigeria: Towards Efficient Government Institutions and Greater Social Responsibility in the Country' [2019] 92 Journal of Law, Policy and Globalization, 78-79, 82 and 89-91.

${ }^{3}$ E. T. Bristol-Alagbariya (2010 [n6]), 3; Department of Political Science, Niger Delta University (n6), 1.

${ }^{4}$ I. Bannon and P. Collier (eds), Natural Resources and Violent Conflict: Options and Actions (The World Bank 2003); F. Allen, Implementation of Oil Related Environmental Policies in Nigeria: Government Inertia and Conflict in the Niger Delta (Cambridge Scholars Publishing 2014); J. S. Omotola (n 11), 73-89.

${ }^{5}$ D. M. J. Fubara (ed), 'The Endangered Environment of the Niger Delta: An NGO Memorandum of the Rivers Chiefs and Peoples' Conference', Port Harcourt, Nigeria, for the World Conference of Indigenous Peoples on Environment and Development and The United Nations Conference on Environment and Development, Rio de Janeiro, Brazil [1992], especially 1 and 16; E. T. Bristol-Alagbariya (2010 [n6]), 73; E. T. Bristol-Alagbariya (2018 [n57]), 32; E. T. Bristol-Alagbariya (2019 [n111]), 79 and 89-91.

${ }^{6}$ Manby B. (n6); O. Douglas and I. Okonta (n6); J. G. Frynas, Oil in Nigeria: Conflict and Litigation between Oil Companies and Village Communities (Lit Verlag 2000); J. G. Frynas, Oil in Nigeria: Community Rights and Corporate Dominance in Conflict (Politics and Economics in Africa) (Lit Verlag 2000); E. T. Bristol-Alagbariya (2010 [n6]), 12-16, 28-34, 45, 196-227, 326-336; E. T. Bristol-Alagbariya, 'Ongoing Reform of the Nigerian Petroleum Industry: The Case of the Oil Producing Communities and Positive Transformation of Nigeria' [2016] 13 (1-2) Environmental and Planning Law Review, 1215-1245; B. Maiangwa and D. E. Agbiboa, 'Oil Multinational Corporations, Environmental Irresponsibility and Turbulent Peace in the Niger Delta' [2013] 48 (2) Africa Spectrum, 71-83; R. Sidaway, Resolving Environmental Disputes from Conflicts to Consensus (Earthscan 2005); A. Onuoha, From Conflict to Collaboration: Building Peace in Nigeria's Oil-Producing Communities (Adonis \& Abbey 2005); P. D. Cameron and M. C. Michael, Oil, Gas, and Mining: A Sourcebook for Understanding the Extractive Industries (World Bank Group 2017); International Institute for Environment and Development (IIED) and World Business Council for Sustainable Development (WBCSD), Breaking New Ground: Mining, Minerals, and Sustainable Development: The Report of the MMSD Project (Earthscan 2002); World Bank Group, 'Striking a Better Balance - The World Bank Group and Extractive Industries: The Final Report of the Extractive Industries Review, World Bank Group Management Response' $<$ http://documents.worldbank.org/curated/en/961241468781797388/pdf/300010GLB.pdf $>$ Accessed 27 March 2020.

${ }^{7}$ Ibid; Population and Human Resources Division, Western Africa Department Africa Region, World Bank, 'Nigeria Poverty in the Midst of Plenty: The Challenge of Growth with Inclusion: A World Bank Poverty Assessment' [1996] Report No. 14733-UNI, World Bank $<$ http://documents.worldbank.org/curated/en/582991468759320261/pdf/multi0page.pdf $>27$ March, 2020; SouthSouth Governors' Forum Nigeria, Braced for Global Competitiveness: Proceedings of First South-South Nigeria Economic Summit, 2009 (South-South Nigeria Economic Summit Committee 2009), particularly 267-269; J. C. Ebegbulem, D. Ekpe and T. O. Adejumo, 'Oil Exploration and Poverty in the Niger Delta Region of Nigeria: A Critical Analysis’ [2013] 4 (3) International Journal of Business and Social Science, 279-287. 
'resource control' movement of the Niger Delta region is designed to address the irony of fate of the oil-rich communities and people of the oil-rich ethnic minority Delta region by advocating that the communities and people of the region deserve to derive maximum benefits in the course petroleum development operations in their communal homelands of the country. ${ }^{1}$

The paradox of poverty in the midst of plenty and peculiar problems of the oil-rich Delta region gave rise to more aggressive discontent, agitation, protests and conflicts ${ }^{2}$ occasioned by the citizens and citizen-groups of the region against the FG and the MNOCs. Consequently, in its characteristic manner, the FG (under the leadership of President Olusegun Obasanjo) had to intervene, by establishing the Niger Delta Development Commission (NDDC), through the enactment of the NDDC Act. 2000, which formally repealed the OMPADEC Decree, No. 23 of 1992, and dissolved the Commission established thereby. ${ }^{3}$ The NDDC Act, ${ }^{4}$ which considers Niger Delta region to be synonymous with petroleum resources development, is basically designed to serve the functions which the defunct OMPADEC was established to tackle. ${ }^{5}$ The NDDC Act 2000, was amended in $2017,{ }^{6}$ to increase the funding of the NDDC for the effective discharge of its duties and for other related matters. ${ }^{7}$

The wide functions and powers of the NDDC are to sustainably develop the Niger Delta area and to address the ecological and all-inclusive environmental problems of the area being occasioned as a result of petroleum resources development operations in the area. The NDDC is to ensure the physical and socio-economic development of the oil-rich communities of the newly conceived, politically diluted and broadened Niger Delta region and to protect, remediate and rehabilitate the environment in the region. The Commission is also to cater for socio-economic empowerment of the Niger Delta people, so as to actualise sustainable development, premised on human wellbeing, protection and improvement of the environment and physical development and advancement of the Delta region. ${ }^{8}$

The fact that the NDDC Act introduced a politically diluted and expanded idea of the Niger Delta region is a problem because the true Delta region is not only or entirely synonymous with petroleum resources development. Besides, petroleum resources are finite resources. ${ }^{9}$ Thus, after the era of these resources development operations, the NDDC Act's expanded notion of the Niger Delta region would become more obvious and unrealistic to sustain. This misleading categorisation the oil producing States outside the true Delta region should

${ }^{1}$ O. V. C. Okene (ed) (n112), 129-144; E. T. Bristol-Alagbariya (2010 [n6]), 40-43; A. A. Ikein and C. BriggsAnigboh (n113); O. Awolowo, Awo: The Autobiography of Chief Obafemi Awolowo (Cambridge University Press 1960), 174-177, especially 174; AG (Federation) v AG (Abia State) \& 35 Ors (No. 2) [2002] 6 Nigerian Weekly Law Report (NWLR) (Pt. 764), 542-905, [2002] 6 Judgments of the Supreme Court of Nigeria (MJSC) 1 SC; J. I. Elaigwu, The Politics of Federalism in Nigeria (Adonis \& Abbey 2007), 312-315.

${ }^{2}$ I. Bannon and P. Collier (eds) (n117); F. Allen (n117); M. Bavinck et al (eds), Conflicts Over Natural Resources in the Global South: Conceptual Approaches (CRC Press 2014); Hemmati M., Multi-Stakeholder Processes for Governance and Sustainable Development: Beyond Deadlock and Conflict (Earthscan 2002); E. C. Onwuka, 'Oil Extraction, Environmental Degradation and Poverty in the Niger Delta Region of Nigeria' [2005] 62 (6) International Journal of Environmental Studies, 655-662; I. Gary and T. L. Karl (n6), which is dedicated to all those in Africa who are acting courageously to bring transparency and accountability to the use of Africa's oil wealth.

${ }^{3}$ Section 1, Niger-Delta Development Commission (Establishment, Etc.) (NDDC) Act, Act No 6. LFN 2000, Cap N86 LFN 2004, captioned 'Establishment of the Niger-Delta Development Commission, etc'.

${ }^{4}$ Niger-Delta Development Commission (Establishment, Etc.) (NDDC) Act, Act No 6. LFN 2000, Cap N86 LFN 2004.

${ }^{5}$ Section 2, Oil Mineral Producing Areas Development Commission Decree (Decree No. 23 of 1992), captioned 'Objectives of the Commission'; Section 7, Niger-Delta Development Commission (Establishment, Etc.) (NDDC) Act, Act No 6. LFN 2000, Cap N86 LFN 2004, entitled 'Functions and Powers of the Commission, Etc.'.

${ }^{6}$ Niger Delta Development Commission (Establishment), Etc.) (NDDC) (Amendment) Act, 2017.

7 Section 14 (2) (b) (i) and (ii), Niger Delta Development Commission (Establishment), Etc.) (NDDC) (Amendment) Act, 2017.

${ }^{8}$ Section 7, Niger-Delta Development Commission (Establishment, Etc.) (NDDC) Act, Act No 6. LFN 2000, Cap N86 LFN 2004, entitled 'Functions and Powers of the Commission, Etc.'; $c / f$ A. L. Olaolou, 'MNCs and Sustainable Environmental Development: An Assessment of the Niger Delta and Texas' [2008] Proceedings of International Conference on the Nigerian State, Oil Industry and the Niger Delta; M. O. Enyoghasim et al, 'Oil Exploration and Exploitation in Nigeria and the Challenge of Sustainable Development: An Assessment of the Niger Delta' [2019] 9 (4) International Journal of Energy Economics and Policy, 369-380.

${ }_{9}^{9}$ B. C. Black, Crude Reality: Petroleum in World History (Rowman and Littlefield 2014); L. Herkenhoff, A Profile of the Oil and Gas Industry: Resources, Market Forces, Geopolitics, and Technology (Business Expert Press 2014); A. A. Derefaka and A. M. Okorobia (eds), History Concourse 2007: The Future of the Niger Delta: The Search for A Relevant Alternative (Onyoma Research Publications 2008). 
be a food for thought for the FG, especially decision-makers of the government and the National Assembly. It demonstrates a need for further amendment of the NDDC Act, so as to make its provisions align more with petroleum resources development in Nigeria. This may be achieved by renaming the Act as the 'Oil Producing Areas Development Commission Act', or any such other appellation or nomenclature that may address the identified misleading description of the oil producing States and areas. Accordingly, the Commission may be named 'Oil Producing Areas Development Commission' or any other more appropriate nomenclature that may be suitable for the oil producing areas. ${ }^{1}$ Besides, suffice it to say at this juncture that there is only one Niger Delta (Niger Delta region), which is otherwise known as the Nigerian Delta (Nigerian Delta region). Consequently, the erroneous reference to or consideration of the Niger Delta region as the 'Nigerian Niger Delta region' should, at least, meanwhile be instantly corrected in the parlance of the knowledge industry.

\section{Conclusion}

So far, this study has discussed the history and social system of the oil-producing ethnic minority Niger Delta region (Delta region of Nigeria) in an ethnographic, historic and geographic manner. The Niger Delta region has been in existence from time immemorial, as other primordial ethnic nationality areas and regions, which were in existence centuries before the birth of modern Nigeria. In the early times, the people of the Niger Delta region established foreign relations between and among themselves, as people of immediate neigbouring primordial areas. They also established long-distance foreign relations with distant tribes that became parts and parcels of modern Nigeria. On this note, the study discusses trade, commerce, politics and foreign relations associated with the primordial ethnic minority Niger Delta region, which is considered here as the true Niger Delta region. It examines, discusses and analyses the true Ancient Niger Delta region to demonstrate that the region is a distinct area of primordial African civilisation.

Beginning with the examination, analysis and discourse of the term 'delta', the study demonstrates that there is only one (worldwide) Niger Delta region, which is the Southern Minorities area (South-South geo-political zone) of Nigeria. This is the primordial and true Delta region of Nigeria. The study proceeds to discuss the state of affairs in the oil-rich ethnic minority Delta region that generated the enactment of the NDDC Act. On this note, it describes how citizens and citizen-groups of the oil-rich Niger Delta region decried that their region has been a goldmine and pathetic region of Nigeria, due to the paradoxes associated with unsustainable petroleum resources development operations in the communities of the region. These paradoxes undermine the wellbeing of the environment, the citizens and their future generations. The study enumerates the irony of the fate of the true oilrich Niger Delta region and its people by explaining how due to worsening consequences of petroleum development operations, the region became crises-ridden and its environment so degraded, devastated and despoiled, making it about the most endangered Delta region in the world. It highlights that the state of the endangered oil-rich Niger Delta region has continued to be deplorable because of the absence of government social responsibility (GSR) and lack of corporate social responsibility (CSR) measures, particularly social responsibility measures of MNOCs operating in the region. It pinpoints that a common agenda of the agitation of the citizens and citizen-groups of the region has been 'resource control', which is associated with fiscal federalism in the country.

The Niger Delta region's historic 'resource control' movement is designed to address the irony of fate of the oil-rich communities and people of the oil-rich ethnic minority Delta region by advocating that the communities and people of the region deserve to have maximum benefits in the course of petroleum development operations in their communal homelands of the country. This was the state of affairs in the 1990s that made the FG led by President Olusegun Obasanjo, through the National Assembly, to address the age-long problems of neglect and marginalisation that translated into youth restiveness, aggravated by militancy in the oil-rich Delta region, which was disrupting smooth petroleum resources development operations in the oil-producing communities of the region, by enacting the NDDC Act, 2000 that formally repealed the OMPADEC Decree, No. 23 of 1992, and dissolved the Commission established thereby.

The NDDC Act categorises the States of the true Niger Delta region and other oil producing States of Nigeria as oil producing States without considering other peculiarities of these States, such as the history and other distinguishing features of their component ethnic nationalities, kingdoms and communities. Thus, whereas it is true that these States are oil producing States, they are notwithstanding much more than oil producing States in the context of such realities as ethnography, history and geography. Consequently, the true Delta region is unmistakable from the politically diluted, misleading, expanded and therefore unsustainable prevailing idea of the Niger Delta region created by the NDDC Act.

Besides, considering that petroleum as a finite resource, the era of petroleum resources development in Nigeria would be over someday. Consequently, the study argues that the continued existence of the broadened

\footnotetext{
${ }^{1}$ E. T. Bristol-Alagbariya (2010 [n6]), 63.
} 
Niger Delta region would become more inappropriate and unrealistic, when petroleum resources development operations are over (sometime in future). This is a perennial problem that amounts to a food for thought, especially for the FG, its decision-makers and the National Assembly in particular.

We therefore recommend that there is a need for Nigeria's FG, through the National Assembly, to further amend the NDDC Act, to make its provisions align more with petroleum resources development, by renaming it the 'Oil Producing Areas Development Commission Act' or any such other name that would not amount to an opaque description of the oil producing areas of the country. The NDDC may then be renamed the 'Oil Producing Areas Development Commission' or any such other appellation or nomenclature that may address the identified misleading description of the oil producing States and areas. We further recommend that meanwhile the prevailing contradiction of some, who refer to or consider the Niger Delta region as 'Nigerian Niger Delta region' or the 'Niger Delta region of Nigeria' should, at least, be corrected forthwith in the parlance of the knowledge industry, by stakeholders of the industry, particularly scholars, beginning with Nigerian scholars.

\section{References}

Abam A. S., King Ibanichuka (Ado VI) 1816 - 1896: The Last of Okrika's Sovereign Rulers (Samag Stationery 2014).

Adegeye A. J., 'Establishing River Basin Development Authorities as a Strategy for Nigerian Rural Development' [1982] 9 (4) Agricultural Administration, 301-311.

Adler P. J. and Pouwels R. L., World Civilizations (Wadsworth Publishing 2014/Cengage Learning 2015).

Achebe C., There Was A Country: A Personal History of Biafra (Penguin Group 2012).

Akpan N. S. and Akpabio E. M., 'Oil and Militancy in Nigeria's Niger Delta: A "Development Catalyst" or “Development in Reverse”?' [2008] 10 (2) South South Journal of Culture and Development, 265-285.

Akobo M. T., Isoun T. T., Asemota S. (Southern Minorities Movement)/The Willink Commission, NIGERIA Report of the Commission Appointed to Enquire into The Fears of Minorities and The Means of Allaying Them (Southern Minorities Movement [SMM] [reprint] 1996), ii - iii, , 5-6, 94-95 and back cover preview.

Akpan N. S. and Akpabio E. M., 'Oil and Conflicts in the Niger Delta Region, Nigeria: Facing the Facts' [2009] 24 (1) Journal of Social Development in Africa, 9-35.

Akpokodje J. and Salau S., 'Oil Pollution and Agricultural Productivity in the Niger Delta of Nigeria' [2015] 6 (4) Journal of Environmental Economics, 68-75.

Alagoa E. J., A History of the Niger Delta (Onyoma Research Publications 2005), 80, 117, 124, 138 and $153-155$.

Alagoa E. J., 'Long-Distance Trade and States in the Niger Delta' [1970] 11 (3), The Journal of African History, 319-329.

Alagoa E. J. (ed), The Land and People of Bayelsa State: Central Niger Delta (Onyoma Research Publications 1999).

Alagoa E. J., Tamuno T. N. and Clark J. P. (eds), The Izon of the Niger Delta (Onyoma Research Publications 2009), 379, 398 and 481.

Alagoa E. J. and Derefaka A. A. (eds), The Land and People of Rivers State: Eastern Niger Delta (Onyoma Research Publications 2002), 149-172, 324-326, and 331-350.

Alagoa E. J. and A. Fombo A., A Chronicle of Grand Bonny (Ibadan University Press 1972/Onyoma Research Publications 2001), vii-viii, 6-7, 45, 49, 60-67.

Alagoa E. J., Nyananyo B. L. and Allison A. A., (eds), History Concourse 2011: The Niger Delta Environment as Resource and Reserve (Onyoma Research Publications 2012) 217-267 and 223-225.

Allen F., Implementation of Oil Related Environmental Policies in Nigeria: Government Inertia and Conflict in the Niger Delta (Cambridge Scholars Publishing 2014)

Anene J. C., Southern Nigeria in Transition 1885-1906: Theory and Practice in a Colonial Protectorate (Cambridge University Press 2009).

Anderson M. G. and Peek P. M. (eds), Ways of the Rivers: Arts and Environment of the Niger Delta (Regents of the University of California 2002), 251-267.

Andiof J. S. Waddock B. Husted and S. S. Rahman (eds), Unfolding Stakeholder Thinking: Theory, Responsibility and Engagement (Routledge 2017).

Andiof J. S. Waddock B. Husted and S. S. Rahman (eds), Unfolding Stakeholder Thinking 2: Relationships, Communication, Reporting and Performance (Routledge 2017).

Augustine K. and Wigwe C. C., 'The Impact of International Oil and Gas Politics on the Petroleum Industry in Nigeria' [2018] 8 (1) The Journal of Property Law and Contemporary Issues, 142-148.

Awoyemi O., The Impact of Oil Pollution on the Environment of the Oil Producing Communities of Nigeria: A Critical Analysis of the Statutory and Regulatory Provisions in Nigeria (Independent Law Publishing 2014).

Azaike S., Inequities in Nigerian Politics (Treasure Communications Resource 2003).

Barrett L., 'Niger Delta: The True Story’ [2008] 468 January, New African Magazine, 12-20. 
Barrow C. J., 'River Basin Development Planning and Management: A Critical Review. [1998] 26 (1) World Development, 171-186.

Bates F. L. and Bacon L., 'The Community as a Social System' [1972] 50 (3), Social Forces, 371-379.

Bavinck M., Pellegrini L. and Mostert E. (eds), Conflicts Over Natural Resources in the Global South: Conceptual Approaches (CRC Press 2014).

Black B. C., Crude Reality: Petroleum in World History (Rowman and Littlefield 2014).

Blanco E. and Razzaque J., Globalisation and Natural Resources Law: Challenges, Key Issues and Perspectives (Edward Elgar Publishing 2011).

Brass P. (ed), Ethnic Groups and the State (Croom Helm 1985).

Briggs N., Okowa W. and Ndimele O. (eds), The Economic Development of Rivers State: In Commemoration of Port Harcourt Celebration 2013 (Onyoma Research Publications 2013), 60-85, 87, 92, 102-106 and 108.

Bristol-Alagbariya E. T., Governance Towards Sustainable Development in Nigeria: The Role of Strategic Assessment of Decisions \& Actions (Centre for Energy, Petroleum \& Mineral Law \& Policy [CEPMLP]/Dundee University Press [DUP] 2010), 218-261, 268 and 271-276.

Bristol-Alagbariya E. T., 'Nigeria: The Role of Law in Nation-building' (2016) 1 (1) UNIPORT Journal of Public Law, 113-136.

Bristol-Alagbariya E. T., Petroleum Development \& the Environment in Rivers State Nigeria: Fallouts of the UNEP Report on Ogoniland, Environmental Regulatory Standards \& Sustainable Development Laws \& Practices (LAP LAMBERT Academic Publishing 2018), 2.

Bristol-Alagbariya E. T., Participation in Petroleum Development: Towards Sustainable Community Development in the Niger Delta (Centre for Energy, Petroleum \& Mineral Law \& Policy [CEPMLP]/Dundee University Press [DUP] 2010), 4, 31, 35-36, 38-39, 40-43, 51-64, 105-110, 126-130 and 134.

Bristol-Alagbariya E. T. 'The Validity and Enforceability of the Oil Rivers Treaties of Protectorate' [1990] dissertation submitted to the Faculty of Law, Rivers State University of Science and Technology, in partial fulfillment of the requirements for the award of the Degree of Bachelor of Laws (LLB).

Cable J., Gunboat Diplomacy (Palgrave Macmillan 1994).

Cameron P. D. and Michael M. C., Oil, Gas, and Mining: A Sourcebook for Understanding the Extractive Industries (World Bank Group 2017).

Clarke J. D., Yakubu Gowon: Faith in United Nigeria: Faith in a United Nigeria (Frank Cass and Company 1987).

Crowder M., The Story of Nigeria (Faber and Faber 1978), 188-206.

Cui R., Oil Multinationals in Nigeria Human Rights, Sustainable Development and the Law (Anchor Academic Publishing 2015).

Department of Political Science, Niger Delta University, International Conference on The Nigerian State, Oil Industry and the Niger Delta, Conference Proceedings (Harey Publications Company 2008), especially 1.

Derefaka A. A. and Okorobia A. M. (eds), History Concourse 2007: The Future of the Niger Delta: The Search for A Relevant Alternative (Onyoma Research Publications 2008).

Dike K. O., Trade and Politics in the Niger Delta 1830-1885: An Introduction to the Economic and Political History of Nigeria (Greenwood Press 1981).

Douglas O. and Okonta I., Where Vultures Feast: Shell, Human Rights, and Oil in the Niger Delta (Sierra Club 2001).

Ebeku K. S. A., Oil and the Niger Delta People in International Law: Resource Rights, Environmental and Equity Issues (Rüdiger Köppe Verlag Köln 2006).

Enyoghasim M. O., Anochiwa L., Agbanike F. T., Uwazie I. U., Kalu E. U., Onwuka O. K., Okwor S. A., Ogbonnaya I. O., 'Oil Exploration and Exploitation in Nigeria and the Challenge of Sustainable Development: An Assessment of the Niger Delta' [2019] 9 (4) International Journal of Energy Economics and Policy, 369380.

Etekpe A., Ayotamuno Y. M., Nwala U. E., Kariboro J. and Jumbo M. C., Dappa-Biriye: His Contributions to Politics in Nigeria (Onyoma Research Publications 2003) 30-33, 54-57 and 195-243.

Federal Republic of Nigeria, Nigeria at 50: A Compendium: The Official and Authoritative Book about Nigeria (Published on the Golden Jubilee Independence Anniversary www.1stoctober.com Publishing 2010), 27-28.

Flint J. E., Sir George Goldie and the Making of Nigeria (Oxford University Press 1960).

Freeman R. E., Strategic Management: A Stakeholder Approach (Cambridge University Press 2013).

Friedman A. L. and Miles S., Stakeholders: Theory and Practice (Oxford University Press 2006).

Gary I. and Karl T. L., Bottom of the Barrel: Africa's Oil Boom and the Poor (Catholic Relief Services 2003).

Gbemre (Jonah Gbemre) $v$ The Shell Petroleum Development Company Nigeria Ltd. \& 2 Ors [2005] $\mathrm{FHC} / \mathrm{B} / \mathrm{CS} / 53 / 05)$.

Hemmati M., Multi-Stakeholder Processes for Governance and Sustainable Development: Beyond Deadlock and Conflict (Earthscan 2002).

Herkenhoff L., A Profile of the Oil and Gas Industry: Resources, Market Forces, Geopolitics, and Technology 
(Business Expert Press 2014).

Horsfall A. K., The OMPADEC Dream (Inprint Publications 1999), 5.

Ikein A. A., The Impact of Oil on a Developing Country: The Case of Nigeria (Praeger Publishers 1990).

Ikein A. A. and Briggs-Anigboh C., Oil and Fiscal Federalism in Nigeria: The Political Economy of Resource Allocation in a Developing Country (Ashgate Publishing 1998).

Ikime O. (ed) (Historical Society of Nigeria), Groundwork of Nigerian History (Heinemann Educational Books (Nigeria) 2004), 393-481.

Ikime O., Niger Delta Rivalry: Itsekiri Urhobo Relations and the European Presence, 1884-1936 (Longman 1970).

Jaja S. and Jaja E. A., Aspects of British Gunboat Diplomacy -Jaja King of Opobo (BMO Publishing 2015).

Johnston J. F., No Man Can Serve Two Masters: Shareholders versus Stakeholders in the Governance of Companies (The Social Affairs Unit 1998).

Jones G. I., The Trading States of the Oil Rivers: A Study of Political Development in Eastern Nigeria (Oxford University Press 1963/James Currey Publishers 2000).

Ken Wiwa et al. $v$ Brian Anderson et al., Case No. 01 Civ. 1909 (KMV) (HBP) (SDNY).

Kiobel v Royal Dutch Petroleum Company [2013] US 133 S Ct. 1659.

Lugard F. J., 'Lugard in Nigeria: Report on the Amalgamation of Northern and Southern Nigeria and Administration, 1912-1919' (Unpublished Reports of Library of African Study: Routledge 2004).

Manby B., The Price of Oil: Corporate Responsibility and Human Rights Violations in Nigeria's Oil Producing Communities (Human Rights Watch 1999), especially 176.

Manirabona A. and. Cárdenas Y. V., Extractive Industries and Human Rights in an Era of Global Justice: New Ways of Resolving and Preventing Conflicts (LexisNexis Canada 2019).

Niger Delta Development Commission (NDDC), Niger Delta Regional Development Master Plan (NDDC 2006) 49-50, 53-55 and 60-67.

Nnoli O., Ethnic Politics in Nigeria (Fourth Dimension Publishers1980).

Obasanjo O., My Command: An Account of the Nigerian Civil War, 1967-1970 (Heinemann 1981).

Ogidiolu A., 'Effects of Gas Flaring on Soil and Vegetation Characteristics in Oil Producing Region of Niger Delta, Nigeria' [2003] 1 (1), International Journal of Ecology and Environmental Dynamics, 47-53.

Ogbuigwe A., Legal Issues in the Niger Delta Resource Dilemma: A Collection of Essay (Anpez Centre for Environment and Development 2018) 7-10.

Ogbuigwe A., Offended: Legal Issues in the Niger Delta Struggle (Anpez Centre for Environment and Development 1999) especially 2-43 and 187-193

Ogidiolu A., 'Effects of Gas Flaring on Soil and Vegetation Characteristics in Oil Producing Region of Niger Delta, Nigeria' [2003] 1 (1), International Journal of Ecology and Environmental Dynamics, 47-53.

Ogundele, A. T., 'River Basin Development Authorities in Nigeria: The Neglected Tools for National Development' [2019] 5 (3), International Journal of Advanced Academic Research: Sciences, Technology and Engineering, $39-49$.

Ojakorotu V. (ed), Fresh Dimensions on the Niger Delta Crisis of Nigeria (JAPSS Press 2009).

Ojakorotu V., Oil Exploitation and Conflict in the Niger-Delta Region of Nigeria (APSS Press 2009).

Okene O. V. C. (ed), Readings in Law and Policy (Current Issues and Trends): (In Commemoration of the Golden Jubilee of Rivers State (1967-2017) (Faculty of Law, Rivers State University 2017) 129-144.

Okolo P. O., Raymond A. O. and Iweka H. I., 'The Need for Ethnic Integration in the Niger Delta Region of Nigeria: A Focus of Western Niger Delta' [2014], Developing Country Studies, 152-163.

Olaolou A. L., 'MNCs and Sustainable Environmental Development: An Assessment of the Niger Delta and Texas' [2008] Proceedings of International Conference on the Nigerian State, Oil Industry and the Niger Delta.

Oluduro O., 'Oil Exploitation and Human Rights Violations in Nigeria's Oil Producing Communities' [2012] 25 (2) Afrika Focus, 160-166.

Omeje K., High Stakes and Stakeholders: Oil Conflict and Security in Nigeria (Routledge 2016).

Omofonmwan S. I. and Odia L. O., 'Oil Exploitation and Conflict in the Niger-Delta Region of Nigeria' [2009] 26 (1) Journal of Human Ecology, 25-30.

Omotola J. S., 'From the OMPADEC to the NDDC: An Assessment of State Responses to Environmental Insecurity in the Niger Delta, Nigeria' [2007] Africa Today, 73-89.

Onoh I., Niger Delta and the Oil and Gas Industry: A Critique of the Impacts and Human Right Implications of the Oil and Gas Industry in the Niger-Delta (LAP LAMBERT Academic Publishing 2011).

Onwuka E. C., 'Oil Extraction, Environmental Degradation and Poverty in the Niger Delta Region of Nigeria' [2005] 62 (6) International Journal of Environmental Studies, 655-662.

Oyebode A., 'Treaties and the Colonial Enterprise: The Case of Nigeria' [1990], 2 (2) African Journal of International and Comparative Law, 17-36.

Oyende K., Oil Pollution Law and Governance in Nigeria (Stirling-Horden Publishers 2017).

Poser N. S., Lord Mansfield: Justice in the Age of Reason (McGill-Queen's University Press 2013). 
Rexler J., 'Beyond the Oil Curse: Shell, State Power, and Environmental Regulation in the Niger Delta' [2010] 12 (1) Stanford Journal of International Relations, 26-31.

Somerset v Stewart [1772] 98 ER 499.

South-South Governors' Forum Nigeria, Braced for Global Competitiveness: Proceedings of First South-South Nigeria Economic Summit, 2009 (South-South Nigeria Economic Summit Committee 2009), particularly 267-269.

Southern Minorities Movement, Appraisal of the Nigerian Crisis and Solution (Southern Minority Movement 1995).

Southern Minorities Movement, Roots, the Struggle and the Future (Southern Minority Movement 1995).

Southern Minorities Movement, What All Southern Minorities Must Know (Southern Minority Movement 1995).

Suberu R. T., Ethnic Minority Conflicts and Governance in Nigeria (Spectrum 2003).

Suberu R. T., Federalism and Ethnic Conflict in Nigeria (United States Institute of Peace 2001).

Udoma U., History and the Law of the Constitution of Nigeria (Malthouse Press 1994), 195-238.

United Nations Environment Programme [UNEP], Environmental Assessment of Ogoniland (UNEP 2011).

Uzoma A. C. and Mgbemena O. O., 'Evaluation of Some Oil Companies in the Niger Delta Region of Nigeria: An Environmental Impact Approach' [2015] 3 (2), International Journal of Environment and Pollution Research, $13-31$.

Wise S. M., Though the Heavens May Fall: The Landmark Trial That Led to the End of Human Slavery (Da Capo Press 2006).

The Willink Commission, NIGERIA Report of the Commission Appointed to Enquire into The Fears of Minorities and The Means of Allaying Them (Her Majesty's Stationery Office [HMSO] 1958).

Wiwa $v$ Shell Petroleum Development Company of Nigeria Limited (SPDC), 04 Civ. 2665, (SDNY).

Wiwa et al. v Royal Dutch Petroleum Company, et al., Case No. 96 Civ. 8386 (KMW) (HBP) (Southern District of New York [SDNY]). 